Journal of Digital Food, Energy \& Water Systems, 2 (2): 77-120, 2021

ISSN 2709-4529

(C) Centre for Cyber Physical Food, Energy \& Water Systems

\title{
Assessing Theoretical Frameworks, Human Resources Management Implications and Emerging Technologies on the Water, Energy and Food (WEF) Nexus
}

\author{
Love Opeyemi DAVID, \\ University of Johannesburg, South Africa. loveopeyemidavid@gmail.com \\ Omoseni Oyindamola ADEPOJU \\ Lead City University, Ibadan, Nigeria.
}

\begin{abstract}
Water, energy, and food (WEF) resources are three vital resources needed for human wellbeing; however, there exists an interaction among the resources. The interactions of water, energy, and food resources resulting in the WEF nexus thinking have been conceptualized as an integrated framework to achieve the security of the three vital resources. However, there are some gaps in WEF nexus research, which constrains the understanding and actualization of the nexus. Hence, this review paper aims to assess theories, human resource management implications, and emerging technologies' effect in understanding the nexus for its actualization. The research employed a qualitative research methodology to achieve the research objectives. The research findings revealed six (6) significant theories that can aid the understanding and actualization of the WEF nexus. The research also revealed that human resource management is strategic, highlighting the need for nexus thinking among human resources. Furthermore, the study revealed the three major emerging technologies of Artificial Intelligence, Big data analytics, and Internet of Things (IoT), which are shaping the WEF nexus through innovations and shaping the nature of the nexus. The study concluded that there is an interaction between the theories and human resources management for attaining the WEF nexus, which affects the extent of the sustainability of the innovations introduced by the emerging technologies. The study recommended quantification of the theories, training on nexus thinking of the current human resource in the WEF sectors, and capital investment on emerging technologies in the WEF nexus.
\end{abstract}

Keywords: Water, Energy, Food, Theories, Human Resources, Emerging Technologies. 
Journal of Digital Food, Energy \& Water Systems, 2 (2): 77-120, 2021

ISSN 2709-4529

(C) Centre for Cyber Physical Food, Energy \& Water Systems

\section{Introduction}

Water, energy, and food resources are indispensable in sustaining humanity, poverty reduction, and ensuring that development is sustainable. However, Botai, et al., [12], Leck, et al., [63] and Hoff [53] researches show that there exist interactions, interlinkages, and interconnectedness among the three resources, leading to the idea of a WEF nexus. According to the authors, this is evident in the fact that the actions of one sector of the WEF resources, directly and indirectly, affect the other sectors' activities. According to Ghodsvali, et al., [45], these inevitable effects among the three sectors are somewhat competitive and can result in conflict. This is because of the usefulness of one resource in producing another resource, as opined by Endo, et al., [36]. The World Economic Forum [142] averred that the WEF nexus is about securing the individual resources and managing their tradeoffs, in terms of accessibility, affordability, availability, stability, and productivity, given their sectoral security. According to UNESCO [131] and UN - WATER [129], water security is "the capacity of a population to safeguard sustainable access to adequate quantities and acceptable quality of water for sustaining livelihoods, human well-being and socioeconomic development for ensuring protection against water-borne pollution and waterrelated disasters, and for preserving ecosystems in a climate of peace and political stability". The International Energy Agency, IEA [55] opined that energy security is "an uninterrupted availability of energy sources at an affordable price while respecting environmental concerns." In addition, the United Nation [128] defined energy security as "access to clean, reliable and affordable energy services for cooking, heating, lighting, communication and productive uses". The Food and Agriculture Organization, FAO, [40] defined Food security as "the availability and access to sufficient, safe and nutritious food to meet the dietary needs and food preferences for an active and healthy life".

Moreover, the growing demand and consumption for WEF resources lead to scarcity in natural resources and global warming, climate change, extreme weather conditions, droughts, and floods, which indirectly damage water infrastructure, electrical systems, and food crops. The nexus management of natural resources such as water, energy, and food (WEF) has been proposed to meet these issues confronting humankind. The WEF nexus is a global response for concurrently assessing how the various approaches of achieving the security of water, energy, and food, can be operationalized.

However, several researchers have worked on the concept of WEF nexus, developing several conceptual frameworks but lacking theoretical frameworks. To the best of the 
Journal of Digital Food, Energy \& Water Systems, 2 (2): 77-120, 2021

ISSN 2709-4529

(C) Centre for Cyber Physical Food, Energy \& Water Systems

researchers ' knowledge, there is a shortage of research on comprehensive theories underpinning the nexus of the three resources. This is a significant gap in the integrated framework, considering the importance of theories in research, which this paper fills. According to Pigott [97], theories aid in understanding the underlying relationships and principles guiding a concept. The author further opined that theories aid the planning of data analysis, as theories aids researchers accountable to data. Anfara \& Mertz [4] earlier posited the same perspective, that theory clarifies relationships between abstractions to understand a phenomenon. To Lederman and Lederman [64], a combination of theories or one theory constitutes a theoretical framework. According to Bradbury - Jones, Taylor, and Herber [14], they are mostly used in qualitative papers, such as the concept of WEF nexus. According to Collins and Stockton [25], a theoretical framework uses theories in research that provide an articulated lens or signpost on how the study in view will process new knowledge. According to the authors, a theoretical framework entails the connection of prevailing knowledge about a phenomenon, a researcher's epistemological dispositions, and the approach for research.

To Grant and Osanloo [47], a theoretical framework is a blueprint for a research inquiry, providing structures and vision for the research. Meleis [83], as cited by Bradbury - Jones, et al., [14], a theory is "an organized, coherent, and systematic articulation of a set of statements related to significant questions in a discipline that are communicated in a meaningful whole." It is a symbolic portrayal of aspects of reality that are discovered or invented for describing, explaining, predicting, or prescribing responses, events, situations, conditions, or relationships. Theories have perceptions that are related to the discipline's phenomena. These perceptions are associated with each other to form theoretical statements." The WEF nexus concept, since its popularization by Hoff [53], have been viewed from different perspectives but lacks a theoretical framework which is a qualitative research problem in the concept, which is most common to qualitative research as lack of identification of significant theories and articulation of the theories of a major hurdle in qualitative research [85, 27]. In the view of Leeming [65], theories aid the understanding of research findings, thereby boosting knowledge development. This was corroborated by the findings of Mueller and Urbach [88] that theories are a reasoning process that enables researchers to draw conclusions from research and make appropriate predictions. Hence, this paper makes available a theoretical framework for research entailing the water, energy, and food nexus, by proposing several theories for proper understanding of the phenomenon and institutions for the integrated concept. The theories will also give researchers, policy 
Journal of Digital Food, Energy \& Water Systems, 2 (2): 77-120, 2021

ISSN 2709-4529

(C) Centre for Cyber Physical Food, Energy \& Water Systems

makers, and economic experts on how to manage the three resources and the nexus of the resources.

Moreover, as the theories of the WEF nexus guide its implementation and understanding of its depth, it highlights a human resources management lacuna in the integrated concept. There is also no research on the implications and effects of human resource management on the nexus of the three resources. Human resource administration generally entails procuring, utilizing, and rewarding human resources. This is especially needed considering that the WEF nexus requires integrated thinking that needs human resources in the WEF sectors with a nexus thinking approach than the current prevailing silo thinking prevailing in the three sectors [72]. According to Armstrong [5], human resource management is a premeditated, coherent, and integrated methodology to the employment, wellbeing, and development of work force working in an organization. It is a process by which management builds an organizational workforce by creating the human performances that the organization needs [13]. To Storey [124] cited in Osinbanjo \& Adeniyi [94], human resources management is "a distinctive approach to employment management which seeks to achieve competitive advantage through the strategic deployment of a highly committed and capable workforce, using an integrated array of cultural, structural and personnel techniques." In the research of O'riordan [92] and Armstrong \& Taylor [6], human resources management goals include the following;

a. Supporting organization objectives via developing and implementing human resources strategies integrated with business strategy.

b. Contributing to developing high - performance culture.

c. Ensuring that talented and skillful people are in the organization.

d. Creating an environment of mutual trust between management and employees

e. Encouraging the application of a principled approach to public's administration.

Therefore, it is of utmost importance to comprehend human resources management's implication in the WEF nexus, considering labor laws, sectoral employment procedures, skill development $\&$ training, compensation arrangement, interdepartmental collaboration, and inter-sectoral coopetition.

Furthermore, while the theories and human resource management aid in a better understanding of the WEF nexus, emerging technologies will shape the actualization of the WEF nexus. Emerging Technologies such as Big data analytics, the Internet of Things (IoT), and Artificial Intelligence, among others, are shaping the intersection of the three resources 
Journal of Digital Food, Energy \& Water Systems, 2 (2): 77-120, 2021

ISSN 2709-4529

(C) Centre for Cyber Physical Food, Energy \& Water Systems

and providing a structural framework for managing the tradeoffs and synergies of the resources, considering different geographical scales. According to Halaweh [50] research, emerging technologies are science-oriented innovations that have the likelihood to transform a current industry or build a new industry, which is often a product of research. Daniel, et al. [29] stated that emerging technologies are not common but commercially available but could be common in the next five years.

Hence, emerging technologies are technologies that are just arising out of research procedures or being tested for commercialization in different research fields. This is highly necessary for the water, energy, and food space considering the interaction, synergies, and tradeoffs of the resources will require different technology arrays, which according to Coles and Hall [24], is a significant challenge nexus thinking. Hence, it is imperative to empirically analyze and identify the emerging technologies in the water, energy, and water nexus to actualize the nexus, which this paper tends to achieve.

Succinctly, in contributing to ensuring the proper management, governance, regulation, and interaction for the actualization of the nexus, this research seeks to empirically make available a theoretical framework for WEF Nexus, identify human resources management implications and examine the emerging technologies that will knit the theories and human resources together for the nexus. This will bridge the existing gap in the literature regarding the attainment of the WEF nexus integrated framework to achieve water, energy security, and food security.

\subsection{Methodology}

This research is a review paper based on qualitative research methodology. This methodology entails analyzing empirical literature to contextualize opinions and juxtapose concepts, aiding a researcher to have in-depth insights into a phenomenon [2]. According to Snyder [120], reviewing literature as a form of methodology aids research finding synthetization in uncovering research areas that need more details in understanding. Therefore, this paper did a structural, logical, and strategic review of relevant literature in top-ranked journals, editorials, book chapters, and publications. 
Journal of Digital Food, Energy \& Water Systems, 2 (2): 77-120, 2021

ISSN 2709-4529

(C) Centre for Cyber Physical Food, Energy \& Water Systems

\subsection{Discussions}

\subsection{Theoretical Framework of Water, Energy, and Food (WEF) Nexus}

The water, energy, and food (WEF) nexus is a multifaceted concept that gives the individuality and complexity of the three energy, agriculture, and water sectors, which are all indispensable in human endeavors. However, the efficiency and Modi operandi of the nexus is established on some theories. This paper proposes the following theories as theories to be understood in ensuring the nexus of the three resources; Secularization theory, Game theory, Malthusian theory of population, and Institutional theory deals with the process of WEF nexus, while Technology Acceptance model theory and the Innovation Diffusion theory deals with the output of WEF nexus. Hence, the theoretical framework for WEF nexus as established from relevant literature, are explained succinctly.

\section{a. Secularization theory}

The security of the three resources was brought forward as a security issue at the Bonn2011 Conference [53], echoing the security views of the 2030 water resources group and US national intelligence council. As a matter of expediency, the US's National Intelligence Council [90] predicted that poor nexus management would lead to social, dire geopolitical, and economic repercussions. In showing the expediency and the securitization of the WEF security nexus at the Bonn 2011 conference, there were contributions from the German Government, the International food policy research institute (IFPI), World Economic Forum, world wide fund for nature (WWF), Stockholm International Water Institute (SIWI), Stockholm Environment Institute (SEI), Food and Agriculture Organization (FAO), the World Business Council for sustainable development (WBCSDI), and the Energy and Resources Institute (TERI), which were all consolidated at the United Nation Conference on Sustainable Development (UNCSD) on the 21 of June 2012.

The securitization of the WEF nexus is grounded on the historical facts that the world has crossed at least three of the nine planetary boundaries of climate change, aerosol loading, species extinction, ocean acidification, ozone depletion, changes in land cover, freshwater usage, usage of chemical, and nitrogen - phosphorus cycles disruption [38; 102]. In addition, the WEF nexus is seen as a security phenomenon because of the projected increase in resource utilization compared to resource availability. According to Hoff [53] and the World Economic Forum Water Initiative [141], about one billion persons worldwide do not have accessibility to drinking water that is clean and not polluted, more than one billion 
Journal of Digital Food, Energy \& Water Systems, 2 (2): 77-120, 2021

ISSN 2709-4529

(C) Centre for Cyber Physical Food, Energy \& Water Systems

people are suffering from hunger, and about 1.3 billion do not have access to electricity. This is as the world's population is anticipated to grow geometrically, and by 2030 , the world population will need $40 \%$ more energy, 30\% additional water, and 50\% supplementary food [90].

According to Leese and Meisch [66], the WEF nexus is a security issue, influenced by the securitization theory of Weaver [135] of the Copenhagen School of security studies. This was also confirmed by the study of Staupe - Delgado [121], which also opined that the security of the three resources is based on the securitization process of the securitization theory. This concept of securitization theory has been applied beyond the traditional military field into different areas of human endeavor like nuclear proliferation [15]; HIV/ AIDS [80]; Environmental degradation [41]; Drug Trafficking [117]; and Government stability [138].

The securitization theory was initiated by the Copenhagen School of security studies, originally named Copenhagen Peace Research Institute (COPRI), through the research of Weaver [136], Weaver [135], and Buzan, et al., [17] in their book titled, "Security: A new framework for analysis", and the re-conceptualized research of Balzacq [8]. The securitization theory is how issues are seen and constructed as an "existential threat" [17; 71]. Mclnnes and Rushton [80] stated that the securitization theory is not limited to military threat alone, but issues that affect the core existence of human beings and their survival can be tagged as security issues.

According to Charrett [19], the securitization theory by the Copenhagen school is premised on three principles, which are;

i. The observation of existential threats in five distrusted yet interconnected sectors includes; military sector, environment sector, economic sector, social and political sector. The water, energy, and food nexus threats cut across four of the five sectors.

ii. Security studies should also focus on the interlinking security dynamics or regions.

iii. There must be a social constructivist consideration of security issues through a securitization process of a speech act through this goal in Buzam, et al., [17] "based on a clear idea of the nature of security, securitization aims to gain an increasingly precise understanding of who securitizes, on what issues (threats), for whom (referent objects), why, with what results and, not least, under what conditions (what explains when securitization is successful)". 
Journal of Digital Food, Energy \& Water Systems, 2 (2): 77-120, 2021

ISSN 2709-4529

(C) Centre for Cyber Physical Food, Energy \& Water Systems

The securitization theory by the school was borne out of the discontent towards the inflexibility of the realism theory, where military aspects and only state are considered matters of security and this discontentment was further stimulated by the Economic agendas and intercontinental environment agendas of the 1980s and 1970s [117]. Hence, Buzan, et al., [17] stated that issues are classified as security issues because security "takes politics beyond the established rules of the game and frames the issue either as a special kind of politics or above politics," where an issue can be classified as politicized, non - politicized or securitized. Buzan, et al., [17], as cited by E Silva \& Pereira [117] opined that this process is the securitization theory process, which is explained in the following concept;

a. Non - politicized Issue: A matter is not politicized when the government is not involved directly in dealing with the matter, whereas there is no public sentiment regarding the matter or issue.

b. Politicized issue: An issue is politicized when it necessitates the intervention of government, which sometimes culminates into public policy.

c. Securitized issue: An issue is securitized when the matter is seen as an existential threat, requiring exigent action, and there is a justification of measures beyond the normal political process.

Furthermore, Buzan, et al., [17] emphasized that the securitization of an issue depends on three (3) indispensable components: identifying and classifying a threat as existential; legitimizing the suspension of laws, and adopting emergency actions. Moreover, according to E Silva \& Pereira [117], the securitization theory has three operational categories, which are;

a. Referent object: This unit is under threat (i.e say WEF resources).

b. Securitizing agent: This is the actor who proposes there is a threat and justifies how it is an existential threat to the referent object (i.e the actors at the Bonn 2011 conferences)

c. The functional actors: these actors are involved in the security of the referent object but are playing a unified role than the securitizing agent (i.e, researchers, international organization, etc).

However, in conformity with democratic traits, the securitization process is seen as a danger to democracy; hence, Waever [135] canvass for desecuritization process of the securitization theory, whereby security issues are handled within a regular operation, 
Journal of Digital Food, Energy \& Water Systems, 2 (2): 77-120, 2021

ISSN 2709-4529

(C) Centre for Cyber Physical Food, Energy \& Water Systems

whereby the emergency measures are subjected to the normal policy framework. Waever [135] stated that desecuritizaion involves three strategies; i) the threat should not be addressed as an existential threat, ii) prevention of securitization from becoming a spirally effect and iii) ensuring the issue is seen within the scope of public policy. Hence, depending on the severity of the existential threats, securitization theory, involves securitization process and de - securitization process.

Therefore, the WEF nexus is a security issue that operates under the securitization theory, as the non - availability of these resources is an existential threat to the world. Therefore, world leaders, governments, international bodies, and researchers must follow both the securitization process and de - securitization process, depending on the resources needed in a geographical area.

\section{b. Game Theory}

The water, energy, and food nexus entail collaborations and compromises among the three sectors [53], which brings the interactions among stakeholders in the sectors to the limelight. The interaction among stakeholders in successfully achieving a nexus for the overall benefits of the geopolitical space of the resources is a strategic and systematic endeavor. Hence, the game theory optimizes the nexus's interactive decision-making process. According to Madami, Darch, Parra \& Workman [74], the game theory can solve the WEF nexus complex socio-economic, ecological, and socio-political factors interconnected with the three resources. The authors further stated that this theory is necessary, as it becomes the decision-making process of the nexus, which is complex due to its multi-sectoral, limited understanding of the interdependencies, multi-objectives, competing factors, and multiple stakeholders with their objectives. Madani, et al., [74] further stated that the game theory provides essential insights into the strategic behaviors of WEF resources stakeholders and the analysis of the socio-political dimensions of making WEF nexusrelated policies. The authors also stated that in making policies associated with WEF nexus, the game theory helps in the following dimensions;

a. Facilitate internal decision-making and cooperation about priorities within government bodies, civil services departments, and institutions.

b. Strengthen the approaches and outcomes of negotiation among geopolitical spaces and within WEF resources domain.

c. Seeks solutions to specific questions on resource management at different geospatial scale. 
Journal of Digital Food, Energy \& Water Systems, 2 (2): 77-120, 2021

ISSN 2709-4529

(C) Centre for Cyber Physical Food, Energy \& Water Systems

d. Reconcile multiple long-term aims of different related WEF nexus resources.

e. Provision of robust strategies across different stakeholders with different interests.

f. Management of multiple actors who strategically interact to achieve their objectives is self - optimizing and often divergent.

Moreover, Madani [73] stated that game theory is necessary for resolving conflicts relating to water management, especially in water quality \& quantity, as the theory provides a strategic framework in studying the actions of individual decision-makers in developing acceptable broad solutions. The author further opined that game theory applications in the administration of water resources cover areas such as water locations, water classification, water cost/ benefit analysis, water quality management, ground water management, water allocations among Trans - boundary users, and cooperative bargaining solutions in negotiations revolving energy optimization. This was further corroborated by Wei [137], where he analyzed the operationalization of game theory in the management of water resources. The author stated that game theory had been used in solving the following water resources problems;

a. The cost of distributing joint water resources projects, especially in the wastewater treatment and disposal.

b. The allocation of water rights.

c. Pollution of Transboundary River and intra- Country River, analysis of water policy - making and water dispatch compensation.

In addition, Li \& Zhou [68] analyzed the implication of game theory between government and farmers, who are stakeholders in optimizing farmlands. The author analyzed the three main stakeholders in land optimization: local government, farmers, and central government, where the game theory was utilized in maximizing the different interests of the stakeholders. In analyzing the nexus in energy generation and management, Garcia [44] opined that game theory is needed in supporting decision-making. The author stated that the theory gives valuable insights in designing policies on complex energy - environmental issues, thus supporting the WEF nexus agenda in the following areas;

a. Facilitation of a better knowledge of the dynamics of policies under ambiguity by assessing the interactions of diverse objectives in energy resources-related institutions. 
Journal of Digital Food, Energy \& Water Systems, 2 (2): 77-120, 2021

ISSN 2709-4529

(C) Centre for Cyber Physical Food, Energy \& Water Systems

b. Understanding different agendas from different departments during policy designs increases accountability and risk-sharing mechanisms among the departments.

c. Assess different energy-environmental policy mechanisms across different political agendas and institutions.

According to Madani, et al., [74], games are defined as a mathematical framework, which consists of some players, strategic moves, and payoffs of players (utilities) for a possible mishmash of the outcome of the game, whereby the player's decisions in the game is fueled by their potential gain. According to Scharpf [109], games are a state where the actions of the actor (individual or groups) are interdependent and collaborating, and the choices of all players affect the outcomes. Also, Tesfatsion [127] stated that a game entails of a gathering of decision-makers, named players; some information on each actor during decision making, the assemblage of different promising moves (in terms of actions decision, , plays) by each player that they can play, a procedure and rules determining moves choices of all players, that can collectively determine the outcome of the games, and the preferences of the players. Based on these foundations, the game theory is built upon how players make decisions. Madami [74] stated that the game theory is a mathematical study of cooperation and competition, illustrating how players' tactical interactions lead to outcomes specific to their preferences. According to the author, Game theory predicts how people behave, follow their interests, and conflict occurrence among people on their varying interests, where the players (decision-makers) with their objectives try to outsmart each other. It is a set of systematic tools premeditated to model interdependent or interactive circumstances, whereby the rational performance of a player can mark his gain or loss and other players [137].

In a bid to solve gambling problems among the idle nobles of French, Mathematicians in the seventeen century came up with the game theory. This led to the 1913 publication of Ernst Zermebo, proving that "every competitive two-person game possesses the best strategy for both players, providing that both players have complete information about each other's preferences and intentions." However, several proponents and contributors to the game theory emerged, such as James Waldegrave, Pierre de Montmort, Nicholas Bernoulli, Isaac Todhunter, and Emile Bore. However, the 1941 scholarly work of Von Neumann and Oskar Morgenstern cemented the concept of game theory in "Theory of Games and Economic Behavior."

According to Wei [137], Mathematically, a game theory is represented thus; 
Journal of Digital Food, Energy \& Water Systems, 2 (2): 77-120, 2021

ISSN 2709-4529

(C) Centre for Cyber Physical Food, Energy \& Water Systems

$\mathrm{G}_{\mathrm{T}}=\{\mathrm{N}, \mathrm{A}, \mathrm{P}, \mathrm{I}, \mathrm{O}, \mathrm{E}\}$

Where;

$\mathrm{G}-\mathrm{A}$ game

$\mathrm{N}-$ Set of players.

A - Players moves or set of actions, which is also a variable of his decision.

$\mathrm{P}$ - Payoff or utility, which is the value of the outcome of players, based on costs \& benefits of actions and outcomes of each player. It could be either actual or expected payoff.

I - Information set, which is the understanding a player has about other players, such as actors profile, characteristics, and payoff utility in the game.

$\mathrm{O}$ - Outcome of the game is a strategy summary eroding from the moves/ actions combination chosen by all the actors at the end of a game.

E - Equilibrium or equipoises, each player can exploit his payoff.

According to the author, NAPI is acknowledged, as the guidelines of the game and OE are the results of the game, which are subject to the following;

a. Players in the game models are regarded as "intelligent and rational." A rational player means that each player will choose a strategy or an action, which can maximize his expected utility given, he thinks what act other players will choose. In contrast, an intelligent player means that each player understands the situation and knows that others are intelligent and rational.

b. Each player considers his behavior and knowledge, and others while pursuing exogenous arms.

c. Each player has more than one choice or plays.

d. All possible combinations of choices or plays result in a well-defined outcome: lose or win, or mutual losses and gains.

e. The players know the rules of the game and the options of other players, but they do not know the real decisions of other players in advance, whereby every player has to choose options based on the assumption of what other players will choose. 
Journal of Digital Food, Energy \& Water Systems, 2 (2): 77-120, 2021

ISSN 2709-4529

(C) Centre for Cyber Physical Food, Energy \& Water Systems

f. Each player knows that his actions can affect others, and the actions of others affect him.

g. Each player makes the best possible move, knowing that his opponent is also making the best possible move.

According to Raoof and $\mathrm{Al}$ - Raweshidy [99], in game theory, games are categorized into different aspects, which are briefly explained below;

i. Non - Cooperative and Cooperative (coalition) games: It is a type of game, whereby the players are driven by self-interest where the actions of each player are assumed selfish, seeking to improve their payoff, without considering other players. While a cooperative game is a kind of game, those players, through mutual agreements, play to achieve some payoffs, thereby allocating benefits and costs depending on the circumstances, where group or individual contribution depends on other players' actions in the game. For the WEF nexus to succeed, a cooperative game is the best approach, where all players are involved.

ii. Strategic and extensive Game: A strategic game, also called a static or normal game, whereby players decide on some personal decision at the beginning of the game, without having prior material facts about the actions of other players. In extensive games, on the other hand, players have information about other players' choices, thereby players making decisions during the game for appropriate reactions to the actions of other players.

iii. Zero-sum Game: This is a payoff structure, where one player's gain is another player's loss.

iv. Games with Perfect and Imperfect Information: A game with perfect information is when the decision or action of a player is influenced by the knowledge of preceding decisions of other players. Whereas, a game with an imperfect decision is when the player has no facts about the actions of other players during their decision-making.

v. Games with complete and incomplete Information: A game with comprehensive information is when all the elements of the game, the strategies, payoff $\mathrm{s}$, and decisions of each player are common knowledge to all players, which is often seen as an efficient, perfectly perfect competitive game. While a game with incomplete information is when players do not have sufficient information about other players in the game, making predictability difficult. 
Journal of Digital Food, Energy \& Water Systems, 2 (2): 77-120, 2021

ISSN 2709-4529

(C) Centre for Cyber Physical Food, Energy \& Water Systems

\section{c. Malthusian Theory of Population}

Rising population people in the world has been a significant driver in most of WEF nexus conceptual frameworks seen in Hoff [53], World economic forum [142], Bizikova, et al., [10] of the Institute of sustainable development and Mabhaudhi, et al., [72] for South Africa. This is because of the perceived disparity between rising population and WEF resources utilization and depletion. This has also being echoed in the work of Meadows, et al.,[81] about planetary boundaries being crossed by the increasing world population and their activities. These concerns support the views of the Malthusian theory of Population.

The Malthusian theory of population is a philosophy of exponential growth of people (1, 2, $4,8,16,32)$ and arithmetic food supply $(1,2,3,4,5,6,7)$. According to Gupta (2012), the theory is used to plan environmental degradation and poverty rate matters. As Unat [130] cited, the Malthusian theory of population was propounded by Rev. Thomas R. Malthus in his seminal work - "An essay on the principle of population", published in 1978. The theory is premised that food production will increase at an arithmetic progression, while the population will be at a geometric sequence and will be doubled every twenty-five (25) years if not checked. As cited in Chowdhury \& Hossain [22], Malthus opined that according to the reducing yields law, there is decrement for food per capita when there is an increase in population. Rahman [98] explained the two mathematical sequence, which is the pillar of the theory, as follows:

a. Arithmetic Progression (AP): It is a mathematical rule of $1,2,3,4 \ldots$. , where the difference between consecutive terms is constant. According to the Malthusian theory, it is term slow sluggish progression when applied to food production. Hence, if there is an increase in food production at the rate of 1, 2, 3, 4,5, when population doubles (according to the theory), the added population food demand will not be met.

b. Geometric Progression (GP): It is a mathematical rule of $1,4,8,16$, where the difference between consecutive numbers is in a ratio of multiplication form, unlike the AP, which is in addition form. Per the theory, the population takes the GP rate. Hence, if there is a $10 \%$ increment in population in two years, then there wouldn't be an increase in food for the excess population but will increase the demand by $10 \%$ for food. 
Journal of Digital Food, Energy \& Water Systems, 2 (2): 77-120, 2021

ISSN 2709-4529

(C) Centre for Cyber Physical Food, Energy \& Water Systems

Rahman [98] furthered posited the Malthusian theory of population using this Illustration "Suppose 1 Million metric tons of Rice is required daily for a country's population. If the country's population increases one-fold after five years, then the demand for food will increase two-fold, requiring 2 million rice metrics for a one-fold population. But it is not possible to produce more food rather than the population".

The Malthusian theory of population by T.R Malthus is based on the following facts, as inferred from Sakanko \& David [108]:

a. The population will always increase due to the natural instinct of sex of human beings, making it grow at a faster rate.

b. The workings of the law of diminishing returns, which posits that adding an additional factor of production results in smaller increases in output.

c. The assumption of a fixed quality of land for production of food and as population gains more land to build houses and other endeavors, thereby depriving the land of agricultural activities or cultivation.

Moreover, as cited by Sakanko \& David [108], Rahman [98], and Seth [116] and Chand [18], Malthus, in his theory, proposed two checks to control population growth, to balance up with food production rate. They are:

a. Preventive check: this check deals with controlling the birth rate through late marriage, celibacy, family planning, abstaining from birth control, procreation, and homosexuality.

b. Positive or natural checks: This check deals with the increase in death rates, which will occur if preventive checks are not in place. The positive checks include; war, diseases, and famine. In complementing this natural check, as cited by Rahman [98], Malthus wrote explicitly - "Famine seems to be last, the most dreadful resource of nature. The power of population is so superior to the power of the earth to produce subsistence for man that premature death must visit the human race in some shape or other. The vices of humankind are active and able ministers of depopulation. They are precursors in the great army of destruction and often finish the dreadful work themselves. But should they fail in this war of extermination, sickly seasons, epidemics, pestilence, and plague advance in a terrific array and sweep off their thousands and tens of thousands. Should success 
Journal of Digital Food, Energy \& Water Systems, 2 (2): 77-120, 2021

ISSN 2709-4529

(C) Centre for Cyber Physical Food, Energy \& Water Systems

be still incomplete, gigantic inevitable famine stalks in the rear; and with one mighty blow levels the population with the food of the world."

Furthermore, Rahman [98] stated that a Malthusian catastrophe would occur whenever there is an increment in population and a decrease in food production. In addition, the author opined that whenever either the preventive checks or positive checks occur, there is a monetary balance between population and food supply, but this is a cycle called the Malthusian cycle.

Moreover, the Malthusian catastrophe, the hallmark of the Malthusian theory of population, emphasizes the growing demand for resources, especially water, energy, and food. Hence, WEF nexus, which is majorly about managing the synergies and tradeoffs of the resources for resources security in line with resource demand and expected population increase, is a solution to wade off the prediction/ prophecy of the Malthusian theory of Population. The pessimistic theory is now an environmental management stimulus in ensuring that population growth and the existing population have enough resources to cater to their wellbeing. This is also in line with the concept of sustainable development, which emphasizes ensuring that resources are craftily managed in catering for today's population and tomorrow's population, which is the fear of the Malthusian theory. The theory also highlights that in avoiding the predictions of the possibility of the positive checks of the theory, stakeholders, government and population must ensure effective resource leadership, which the WEF nexus represents. This is because of the critical role water and energy plays in ensuring food production and supply.

The theory has been used for the relationship between income and population from 17 OECD countries by Madsen, et al.,[76]; between per capita growth and population in India by Chowdhury and Hossain [22]; the relationship between fertility and poverty rate in Turkey by Ozturk [95]; and the relationship between development, and population growth in Sub - Saharan African countries by Eren [37]. All these empirical studies show the relevance, importance, and validity of the possibility/ effect of the Malthusian theory of population, as all relate to resource optimization.

However, as Okunola, Nathaniel and Festus [93] stated, the Malthusian theory has been heavily criticized, whereby some of the criticism is aiding the WEF nexus. These criticisms are summarized as follows;

a. The wrong mathematical form of the theory as there are no empirical proofs. 
Journal of Digital Food, Energy \& Water Systems, 2 (2): 77-120, 2021

ISSN 2709-4529

(C) Centre for Cyber Physical Food, Energy \& Water Systems

b. Malthus failure to foresee opening of new areas in Australian, United States of America and Argentina, where there is extensive farming of virgin land, unlike his local area of England.

c. Failure to see unprecedented increase in scientific knowledge, Agricultural inventions and technological breakthroughs in Agriculture.

d. Malthus neglected the Manpower aspect of population, that an increase in population means an increase in Manpower for agricultural activities.

e. The Malthusian theory rest on a weak relationship between food supply, and population, as population is more related to total wealth.

f. Empirically, it has been proven that population growth is a function of the level of per capita income, because when per capita increases, it lowers fertility rates and the rate of population growth therefore declines.

\section{d. Institutional Theory}

The water, energy, and food nexus is an integral method that cuts across different complex sectors, thus necessitating the application of various policies, rules, procedures, regulations, and norms. The nexus entails the management of the different institutions, their actions, and policies. Scott [114], in his research on the governance of the WEF nexus, opined that the nexus is about how policies and actions in one sector can stimulate constraints by overlooking their impact in the other two sectors, as this integrated approach requires harmonization on public polices, coordination and the alignment of strategies, incentives and regulations. The author further opined that the WEF nexus approach requires the processes and institution of governance. Also, Stein, Barron, and Moss [122] opined that the interconnected challenges of WEF resources, which necessitated the nexus, need the alignment of policies for sustainable development due to the different resource systems, actors, and policy domains that are interconnected. According to the authors, the WEF nexus is about the inseparable relationships between people (who are actors) and their perceptions. Furthermore, the research of Foran [42] had suggested that in the optimization of the WEF resources nexus, the nexus has to be viewed from a social science perspective, considering their historical, socio-political, and cultural dimensions. In addition, the author opined that an understanding of the WEF nexus entails synthesizing fundamental concepts, discourses, interests, and institutions.

These researches: Scott [114], Stein, et al., [122] and Foran [42] have shown that the efficiency and governance of WEF nexus can be attained by factoring in the role of 
Journal of Digital Food, Energy \& Water Systems, 2 (2): 77-120, 2021

ISSN 2709-4529

(C) Centre for Cyber Physical Food, Energy \& Water Systems

Institutions, which is what the institutional theory centers on. According to Scott [113], "Institutions comprises of regulative, normative and cultural - cognitive elements that, together with associated activities and resources, provide stability and meaning to social life". Furthermore, according to Scott [113], as cited by Comyns [26], the three elements of Institutions are briefly explained. The regulative pillar of Institutions deals with establishing, monitoring, and enforcing rules and regulations. The normative elements entail the definitions of goals and how to pursue those goals, while the cultural-cognitive support highlights individual responses to the peripheral world shaped by cultural frameworks. Jepperson [59] stated that Institutions are developing, higher-order factors above the level of individuality but constraining or constituting actors' interests and political participation without repeated authority to achieve regularities.

Institutions are informal or formal procedures, conventions, routines, norms, moral templates, cognitive scripts, and symbols systems in an organizational structure [51]. In addition, Scott [112] and Berthod [9], institutions are rules, roles, beliefs, and symbolic elements that can affect the methods or structure of an organization without resource flow and technical requirements. Paul [96] averred that institutions help in the coordination of actions between diverse actors in a society without the necessity for centralization, which limits. Friel [43] research highlighted scholars' views that institutions govern the actions of individuals and define their preferences and power in a society. Furthermore, according to Williamson [139], Institutions exist at four (4) levels in society. The first level is customs, traditions, religion, and norms, which are subject to change over time but have a lasting impact on the conduct of a society. The second level is the formal rules, consisting of laws and constitutions, which materialize partially out of an evolutionary process and partially out of design. The third level is governance, which entails the conception of contracts and agreements between groups in a society or institutions, which set the basis for mutual benefits and reduction/ avoidance of conflicts. The fourth level of institutions' existence in society is resource allocation.

Institutional theory emphasizes on the activities, relationships, and regulations of institutions over time. Slimane, et al., [119] emphasized how actors in institutions are willing to institutionalize new practices and how organizations within an institution can manage environmental pressure. This management of ecological pressures is a result of institutional practices, which, according to Dimaggio \& Powell [33], are done through Isomorphism. The author stated (as cited by Comyns, [26]) that Isomorphism in institutional theory is in three processes: Mimetic Isomorphism, Coercive Isomorphism, and Normative 
Journal of Digital Food, Energy \& Water Systems, 2 (2): 77-120, 2021

ISSN 2709-4529

(C) Centre for Cyber Physical Food, Energy \& Water Systems

Isomorphism. Coercive Isomorphism entails responding to government regulations due to formal or informal pressure, whereas Mimetic Isomorphism is a process whereby organizations mimic or copy others within the same institutions. Normative isomorphism entails professionalism in the institutions.

Moreover, Lewis, Cardy, and Huang [67] study opined that Institutional theory foreground the complexity of institutions and help skilled actors influence and navigate the social constructions of institutions themselves, which serves as a toolkit in managing the three process of isomorphism. According to the authors, the concept of institutional theory emanates from the scholarly works of Meyer and Rowan's [84] in their study titled "Institutionalized organizations: formal structure as myth and ceremony" and Dimaggio \& Powell [33] in their research titled - "The iron cage revisited: Institutional isomorphism and collective rationality in organizational fields." Meyer and Rowan [84] opined that Institutional theory entails understanding the decision-making process of organizations, which are usually motivated by their environment/ Institutions rather than their efficiency, which often leads to Isomorphism (where organizations in an environment or institutions begin to resemble each other). Starting from where Meyer and Rowan research work stops, Dimaggio \& Powell [33] expanded the Institutional theory by researching Isomorphism and providing mechanisms on how it works in institutions. The authors formulated three processes of Isomorphism as stated earlier, which includes;

a. Coercive Isomorphism: This is a type of Institutional resemblance that occurs due to formal expectations (laws or regulations), informal expectations (corporate social responsibilities and ethics); and the penalties/ sanctions that occurs when these expectations are not met, which includes loss of legitimacy, bans, fines, etc.

b. Normative Isomorphism: This entails codifying rules, norms, routines, and values when different organizations in the same institution become professionalized. These are seen in Institutions such as Education, professional associations, etc.

c. Mimetic Isomorphism: This occurs when organizations within the same institutions tend to reduce search costs in the face of uncertainty and accept Institutional practices by default due to the diffusion of those practices, whereby failure of adoption or copying results in penalties. This also occurs due to environmental uncertainty and the organization's ambitious goals that lead organizations to imitate one another [125]. 
Journal of Digital Food, Energy \& Water Systems, 2 (2): 77-120, 2021

ISSN 2709-4529

(C) Centre for Cyber Physical Food, Energy \& Water Systems

Succinctly, Institutional theory entails how groups and organization within an institution secure their situations and affirms the legality by compatible to rules (such as laws, governmental agencies, regulatory structures, professions, scripts, and other environmental pressures) and norms [46; 33; 84; and 112]. Also, Jennings \& Zandbergen [58] and North [91] opined that Institutional theory studies how an organization in an institution seeks legitimate practices in the views of other stakeholders due to pressures from social, economic, and political environments influences on their decision-making ability.

The theory provides a theoretical lens for identifying and examining internal and external factors that influence the survival and legitimacy of organizational practices, whereby the influencing factors are social environment, culture, regulations, tradition, history, economic incentives, and resources. Institutional theory is also because organizations within the same institutions adopt initiatives in gaining acceptance or legitimacy within society, which helps them access scarce and important resources [23].

Furthermore, Schmidt [110], as cited by Friel [43], in his contribution on Institutional theory, suggested that there are four (4) types of Institutional theory approaches, which shapes actors (organizations or players) in an institution, which includes;

a. Rational choice Institutionalism entails that institutional actors have static preferences and therefore act rationally to maximize their preferences. It is a simultaneous influence exerted on each other by both actors and institutions in maximizing their preferences (for actors) and legitimizing practices (for institutions). March and Olsen [78] opined that the fundamental logic of the rational choice approach is that institutions are arrangements of incentives and rules, where members of Institutions, that is organization and players, behave in response to them, whereby institution influences the actors through rewards for their actions and reduce the uncertainties of their actions.

b. Sociological Institutionalism: This examines how and the extent to which institutional actors follow the norms and rules, assuming that culture and identities are the causes of interest for individuals. It emphasizes how institutions model actors and not how actors form institutions.

c. Historical Institutionalism: It focuses on the development of institutions over time, as they are sets of regularized practices. It is also because the structural and policies made by an institution during inception will have a long-lasting influence over its practice during the course of its existence [123]. 
Journal of Digital Food, Energy \& Water Systems, 2 (2): 77-120, 2021

ISSN 2709-4529

(C) Centre for Cyber Physical Food, Energy \& Water Systems

d. Discursive Institutionalism: This examines the generation and legitimization of ideas by actors through a rationality of communication, focusing on the collaborative process through which concepts are produced.

Therefore, in applying Institutional theory to WEF nexus, it is a mix of different players from both public and private sectors in each of the institutions of water, energy, and food/ Agriculture sectors. The norms, regulations, culture, governance, and environmental pressure are nexus. Hence, Institutional theory underpins the nexus on how the integration of different institutional practices can be achieved, simplified, and sustained over time to create the nexus. This has to do with identifying patterns in each sectoral institution for the internationalization of processes and managing conflicting rules and procedures.

e. The Theory of Technological Acceptance Model

The Water, Energy, and Food nexus, due to its complexity and heterogeneity with other fields and sectors of the economy, the integration of Technology is inevitable. Technology remains the core optimization of the nexus, and the integration between the three resources can only be possible by technology. Several authors have researched the technological aspect of WEF nexus. Martino, et al., (2021) designed a technological aspect of WEF nexus by designing a reverse Osmosis desalination in South Central Texas to decrease water scarcity and meet local water demands in the area. Emmanouil, et al., [35] designed an environmentally friendly renewable energy micro grid for a village in Ethiopia for a sustainable irrigation system for pumping, lighting, and cooking. Endo, et al., [36] also analyzed different methods and tools for achieving WEF nexus, which the bottom line is Technology. Technology, the application of science, is inevitable in achieving WEF nexus for different WEF resources needs or objectives.

However, in designing a technology-oriented WEF nexus, the technology acceptance model theory dealt with the acceptability of such new technology. Davis [30] propounded the Technology Acceptance Model (TAM) theory on how readily people will accept new technology. He demonstrated it at the Massachusetts Institute of Technology (MIT) in the 80 's, on the acceptance of an IBM product [118]. According to the authors, TAM focuses on why users will accept or reject technology and the improvement on the acceptance or rejection. According to Deslond and Becerra [32], TAM predicts the level of technology acceptance and usage, categorized into perceived usefulness and Perceived ease of use. The authors opined that perceived ease of use (PEU) is the degree to which a user believes that 
Journal of Digital Food, Energy \& Water Systems, 2 (2): 77-120, 2021

ISSN 2709-4529

(C) Centre for Cyber Physical Food, Energy \& Water Systems

using a particular technology would require minimal or easy efforts. In contrast, perceived usefulness (PU) entails the extent to which technology enhances job performance.

Furthermore, Wingo, Ivankova \& Moss [140] stated in their research, as seen in figure 1, that five (5) factors contribute to the perceived usefulness of a technology. The first one is the subjective norm, which entails how the users believe other people's perceptions of the technology based on their experience and whether the technology usage is mandatory or voluntary. According to Jaradat \& Almashaqba [57] research, the subjective norm is defined as "the degree to which an individual perceives that most people who are important to him think he should or should not use the system." The second factor, image, is how the technology used will affect the user. According to Moore \& Bensasat [87], image entails "the degree to which an individual perceives that use of an innovation will enhance his or her status in his or her social system." Job relevance, which is the third factor, deals with how the user-perceived that the technology would help accomplish the job's significant goals. In further explaining job relevance, Venkatesh \& Davis [132] defined job relevance as "the degree to which an individual believes that the target system is applicable to his or her job and the effect it has on the job." The fourth factor is the output quality, demonstrating how the quality of the technology will influence the applied task. Venkatesh \& Davis [132] opined that output quality is "the degree to which an individual believes that the system or technology performs his or her job tasks very well" The fifth factor, demonstrability, entails the perceived tangible outputs and benefits of the technology. Moore \& Benbasat [87] defined demonstrability as "the degree to which an individual believes that the results of using a system are tangible, observable, and communicable". 
Journal of Digital Food, Energy \& Water Systems, 2 (2): 77-120, 2021

ISSN 2709-4529

(C) Centre for Cyber Physical Food, Energy \& Water Systems

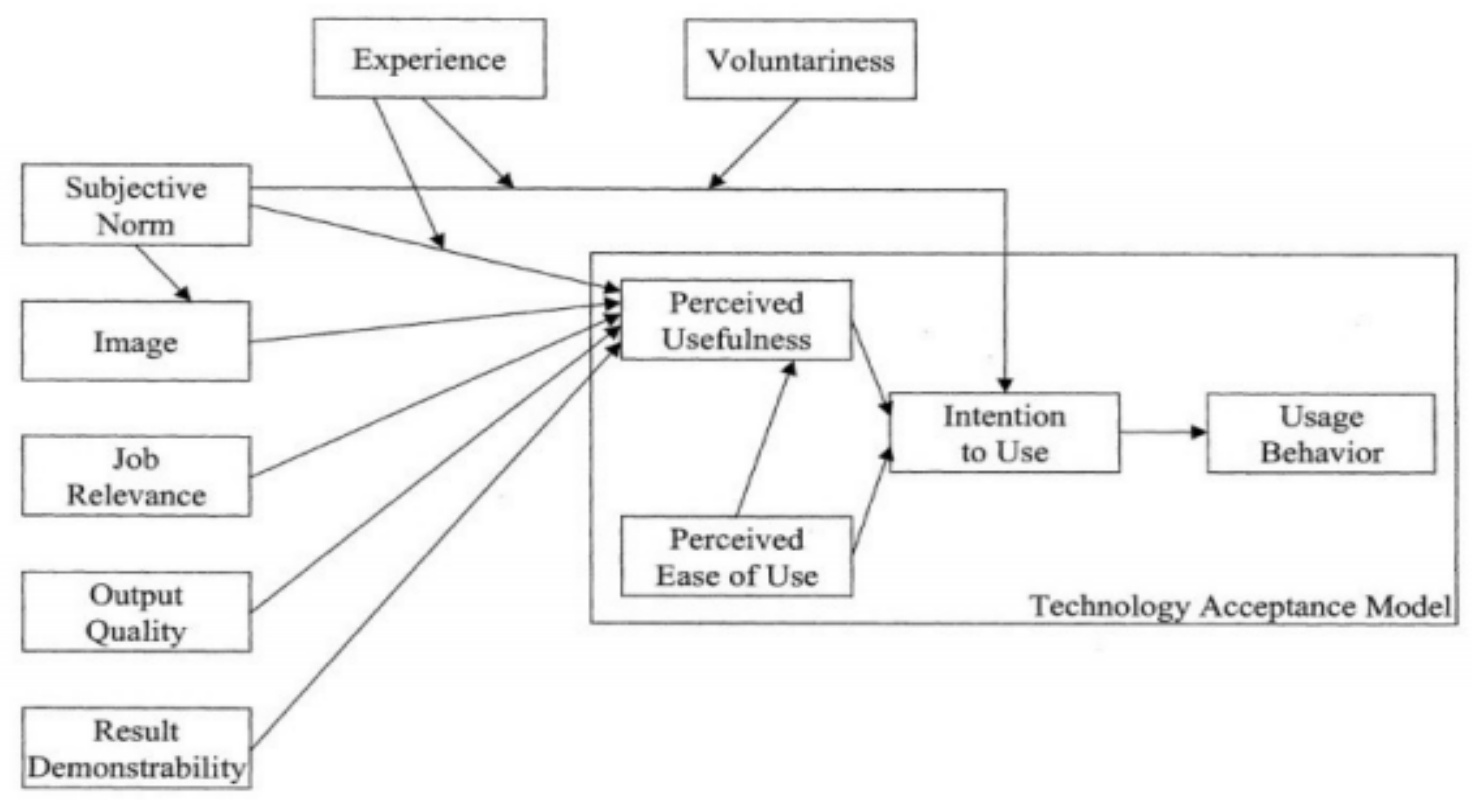

Figure 1: Technology Acceptance Model [140].

Therefore, the use and application of the technologies on the water, energy, and food nexus will be subjected to the acceptance of the technologies grounded on the theory of the Technology Acceptance Model. Users of the WEF nexus will observe the technologies' perceived usefulness and ease of use of the technologies. This, therefore, entails that WEF nexus stakeholders, policy makers, researchers, and project managers should focus on simplifying technologies for easy usage and highlighting the importance of speeding up the acceptance of the technologies.

\section{f. Innovation Diffusion Theory}

Products of the individual three resources of water, energy, and food are innovations at inception; they are produced to bridge a gap or satisfy human needs. Likewise, products from the WEF nexus are innovations, considering their newness and purpose. Robertson [101], as cited in Ja Kim, Lee \& Contractor [56], defined innovation as "a process whereby new thought, idea, behavior or thing is conceived and brought into reality." Mytelka [89] 
Journal of Digital Food, Energy \& Water Systems, 2 (2): 77-120, 2021

ISSN 2709-4529

(C) Centre for Cyber Physical Food, Energy \& Water Systems

also opined that innovation is a procedure by which an organization masters and implement the design and manufacturing of goods \& services that are new to their organization, regardless of whether they are new to their competitors, market, customers, or the world. Therefore, considering the inevitable processes, designs and production, and technological innovation in the three most crucial resources and their nexus, there is a need to understand how these innovations will flow and be sustainable. Rogers [104] defined diffusion as "the process by which an innovation is communicated through certain channels over time, among the members of a social system." Hence, the IDT application to the WEF nexus deals with how the nexus products will be readily diffuse for acceptance or rejection.

Rogers propounded Innovation Diffusion Theory (IDT) in 1962 in his book titled "Diffusion of Innovation", explaining how innovation or technology spread and is accepted among a population. Jwaifell \& Gasaymeh [60] opined that innovation diffusion theory describes the process whereby innovation is adopted among a population. Citing Rogers (2003), the authors opined that in the adoption of technology and experience, it is effective in their activities before accepting or rejecting the technology. Hence, according to Rogers [105] cited by Choe \& Noh [21], IDT is defined "as the process by which an innovation is communicated through certain channels over time among members of a social system".

Rogers [105] stated that the adoption and spread of innovation is determined by five (5) qualities, which are;

a. Compatibility: this entails the perceived consistency with values, needs and experience of possible users \& adopters.

b. Relative advantage: this connotes that the more incredible, easier, and quicker technology adopters realize the benefits, merit, and importance of technology, the fast its rate of adoption.

c. Trialability: this is the extent to which the exploited technology can experiment on a limited basis.

d. Simplicity and ease of use: this is based on the effortlessness of usage and application of the technology. People will quickly adopt an easy-to-use technology than a technology that requires new skills and knowledge. 
Journal of Digital Food, Energy \& Water Systems, 2 (2): 77-120, 2021

ISSN 2709-4529

(C) Centre for Cyber Physical Food, Energy \& Water Systems

e. Observable results: the quicker and easier potential technology adopters see the benefits and results of using technology, the faster it is adopted.

Furthermore, according to Rogers [105] and Sahin [107], there are four (4) main elements in the diffusion of innovation, which comprise creation, time, communication channels, and social systems.

a. Innovation: This is a project, idea, or practice that is professed as new by an individual, even if the innovation has been invented for a long time.

b. Communication channels: This is the process whereby participants produce and share information with each other or among themselves to reach a conclusion or mutual understanding. According to Rogers [105], the communication channels in the IDT entails 5 channels shown in figure 2, consisting of knowledge (this is the why, what and how of the innovation); Persuasion (this is the formation of favorable \& unfavorable attitude towards the innovation based on the degree of uncertainty); Decision (at this stage, the user decides to either accept or reject the innovation); Implementation (the user is putting the innovation to practice) and Confirmation (the user has decided to use the innovation but needs further support to cement their acceptance decision or uncertainty attitude). 
Journal of Digital Food, Energy \& Water Systems, 2 (2): 77-120, 2021

ISSN 2709-4529

(C) Centre for Cyber Physical Food, Energy \& Water Systems

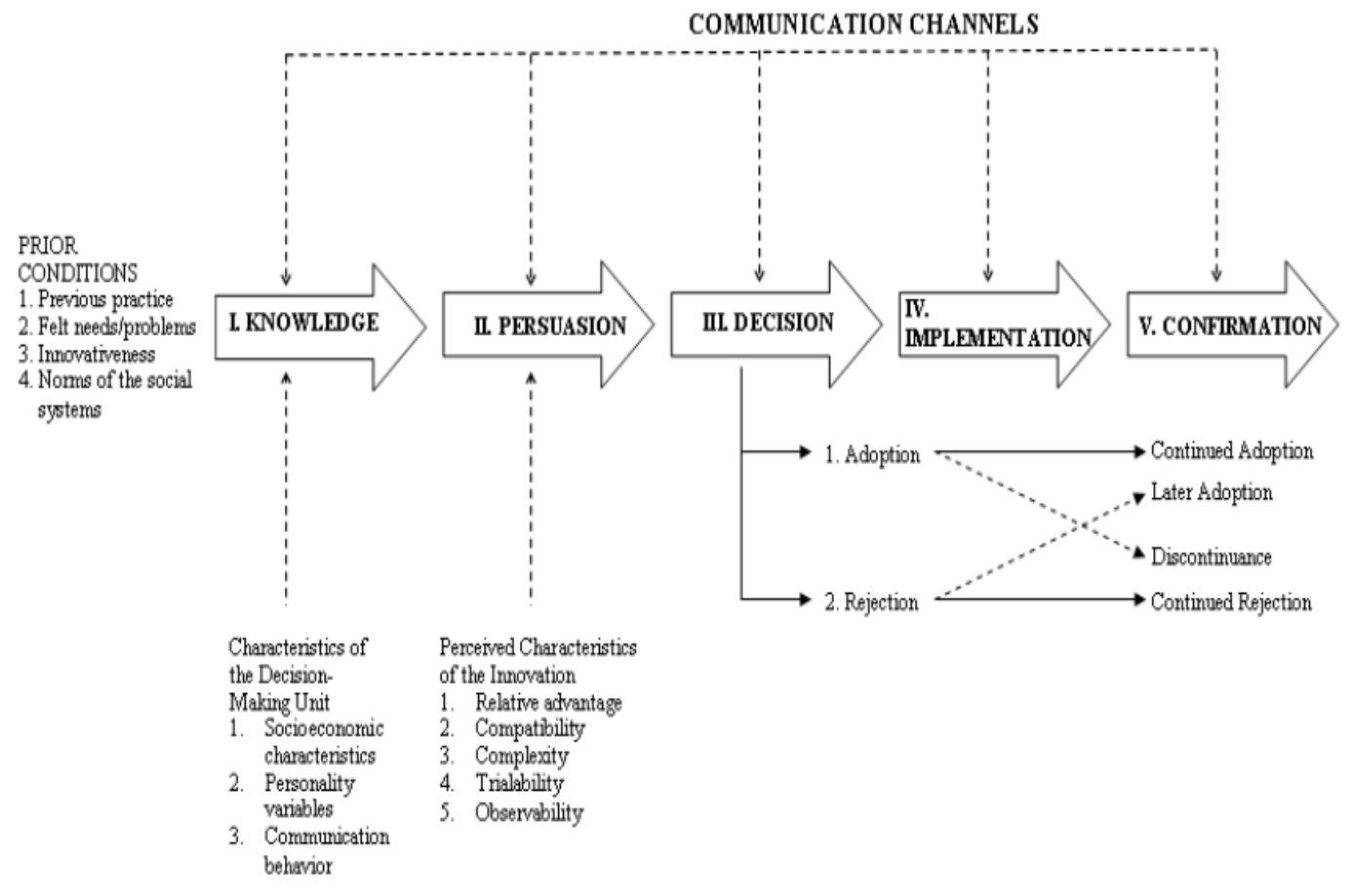

Figure 2: IDT communication channels [105; 107].

c. Time: this entails the period by which people adopt the innovation. According to Rogers [105] and Dearing \& Cox [31], the period of innovation is in accordance with 5 categories of adoptions, which are innovators (2.5\%), early adopters (13.5\%), early majority (34.0\%), late majority (34.0\%) and Laggards (16.0\%). This is shown in figure 3 . 
Journal of Digital Food, Energy \& Water Systems, 2 (2): 77-120, 2021

ISSN 2709-4529

(C) Centre for Cyber Physical Food, Energy \& Water Systems

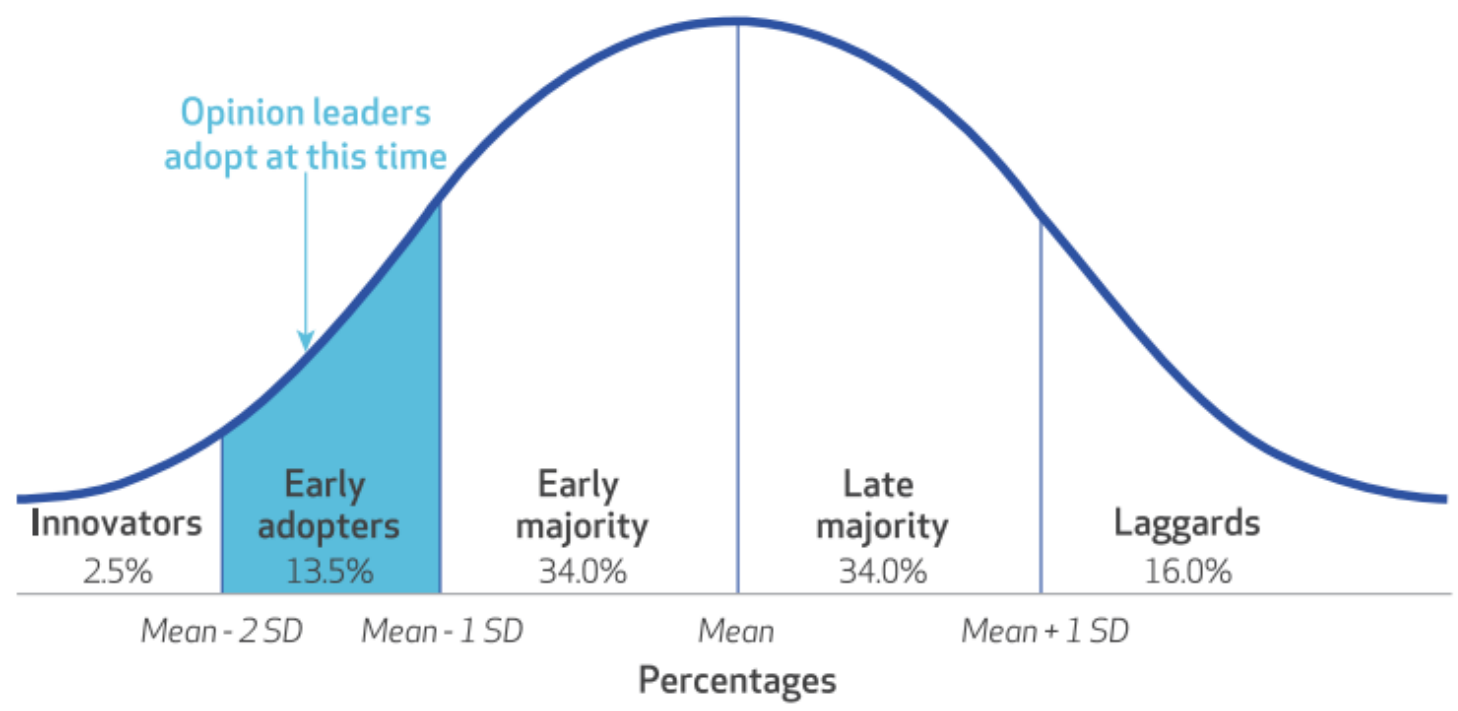

Figure 3: IDT Time of adoption [31].

d. The social system is a set of interconnected units engaged in solving a problem to achieve a mutual goal, which is often influenced by a social structure.

Therefore, the applications of the innovation diffusion theory to the innovation arising from the water, energy and food (WEF) nexus entails that before the acceptance of those innovations, they must be applied in stages and not in a forceful attempt. This will ensure quick acceptance of the innovation and the marketing mechanism and, most importantly, their sustainability. Relevant stakeholders in WEF nexus policy decision-making process must appraise the innovation based on the five (5) communication channels of IDT and the five (5) qualities of the theories.

\subsection{Human Resource Management Implications on WEF Nexus}

The WEF nexus theories have shown the crucial role of human resource management, which is a lacuna in nexus management. The securitization theory introduced by Weaver [135] of the Copenhagen school of security studies has shown that the security of the resources needs human resource managers that will always view the insecurity of the three resources as an existential threat. This lay emphasis on the vision and foresight of the 
Journal of Digital Food, Energy \& Water Systems, 2 (2): 77-120, 2021

ISSN 2709-4529

(C) Centre for Cyber Physical Food, Energy \& Water Systems

leadership in Human resource management. As opined by Zhao, Liu, Zhu, and Liu [144], the administration has an intrinsic value in ensuring the performance of an organization through the utilization of human resources of the organization. Hence, in ensuring the security of the three resources, which is the ultimate aim of the WEF nexus, human resources must be coordinated in channeling their capabilities to view the unavailability of the resources as an existential threat. The Game theory popularized by Madami, et al., [74] revealed the importance of stakeholder engagement and management in making resource management decisions, a key aspect of human resource management practices. To effectively utilize human resources to achieve organizational goals, stakeholders' engagement must be a human resource strategy. This was optimized by Li \& Zhou [68] in maximizing and integrating various stakeholders' interests to achieve food productivity. Therefore, the WEF nexus must utilize this human resource strategy in managing the synergies and tradeoffs of the resources, which involves multiple stakeholders. Stakeholders in the WEF nexus thinking includes WEF resources policy makers, employees in the three sectors, managers in the three sectors, business leaders, corporate organization, researchers in the WEF spaces, and government officials across different tiers/ level of government. In addition, other stakeholders include interest managers from ancillary services such as transportation, community managers, urban \& rural planners, and managers of other WEF drivers like climate change, environment/ ecology, economy, population growth, etc.

Moreover, the Malthusian theory of population introduced by Malthus [77] described the relationship between population growth and food supply, directly and indirectly, emphasizing human resources productivity. This paper opined that the productivity level of human resources in the association between population growth and food supply determines the extent of food supply and diminishes the effect of population growth. Hence, irrespective of the introduction of money, materials, machine, and method, as Hameed [52] stated in an endeavor, until man, which is the human resource, make it work, the efforts will end in a stalemate. Therefore, accentuating the strategic role of human resource productivity will ensure the supply of WEF resources in terms of accessibility, affordability, availability, and stability. However, as Mojelan, Satari, Soleimani \& Daryani [86] stated, human resources must be managed well for optimal productivity. Hence, the WEF nexus security depends on the productivity of human resources, which has formed part of the criticism of the Malthusian theory in ignoring the human resource productivity of population growth. 
Journal of Digital Food, Energy \& Water Systems, 2 (2): 77-120, 2021

ISSN 2709-4529

(C) Centre for Cyber Physical Food, Energy \& Water Systems

Moreover, institutions in the Water, Energy and Water sectors must be strong to ensure human resource productivity. Human resources efficiency and productivity depend on rules and governance structures. This is the hallmark of the Institutional theory, as shown by Scott [114] on policies and regulations alignment that must be followed in the three sectors of water, energy, and food. Therefore, for institutions to be strong and work for intended purposes, there must be an understanding and collaboration between rules and human resources, as rules can't be followed without human resources. The Technological Acceptance model introduced by Davis [30] and the Innovation Diffusion Theory postulated by Rogers [104] bring to the limelight that technologies' optimal performance depends on the acceptability rate of human resources. Therefore, introducing technologies to achieve the nexus of the three resources, especially at the National and geographical scale, requires human resources' buy-in. This shows the importance of human resource engagement for the technology to thrive.

Furthermore, the introduction of the importance of human resources in the theoretical framework of WEF nexus emphasized the utilization aspects of human resource management but was silent on the procurement, compensation, and rewarding aspects. This highlights the importance of recruiting human resources with nexus thinking, which can optimally drive the WEF goals regarding WEF security, climate change management, economic sustainability, environmental sustainability, social sustainability, and sustainable sustainability economy. Lack of nexus thinking among managers of the WEF nexus has been the bane of the nexus. Citing Leck, et al., [63], McGrane, et al., [79] posited that the nexus aims to break down silo mentality among the three resources, acting as a barrier to achieving the nexus of WEF resources. The authors lamented that the translation of "Nexus thinking" into "Nexus doing" has not yet materialized. Hence, this paper believes that for a transition of nexus thinking to nexus doing, human resources in the three sectors must have a nexus thinking, thereby enabling them to study the effect of the policy of one sector on the policy of the sectors. These three resources, mainly under the government's control, require civil servants in charge of policy formation and require a WEF Nexus thinking. It should be an issue of expediency that recruitment into the three sectors should factor in the understanding of the imperative of the interrelationship between one resource to other resources.

Moreover, system mapping of the various linkages of the WEF resources proposed by Terrpon - Pfaff, et al., [126] requires productive human resource managers with nexus thinking. These human resource managers would ensure efficient coordination of the 
Journal of Digital Food, Energy \& Water Systems, 2 (2): 77-120, 2021

ISSN 2709-4529

(C) Centre for Cyber Physical Food, Energy \& Water Systems

management of the interlinkages beyond the occasional input of academics, thereby ensuring the sustainability of the resources. Hence, for the nexus to be translated into the policymaking process, system-level thinking is highly needed, which cannot be achieved with a human resource without nexus thinking. Mabhaudhi, et al., [72]) of the South African Water Research Commission stated the lack of nexus thinking among human resource managers in the energy and Agriculture sector of Mpumalanga and Limpopo provinces of South Africa. Also, Rasul and Sharma [100] opined that lack of nexus thinking among human resources of WEF sectors leads to over-allocation of resources during policy formation.

Furthermore, Gywahi [49] highlights the compensation aspect of human resource management in the WEF Nexus. The author opined that internal rewards by leaders in powerful positions corrupt nexus thinking and enthrones a silo mentality among the WEF resources. Hence, an appropriate compensation and reward system should be introduced to propagate a nexus thinking among human resources of the various departments and agencies of the WEF sectors.

Therefore, this paper advocate for consideration of WEF nexus thinking in the recruitment policy of the sectors of the three resources. This will aid prompt and efficient management of the three resources' interdependencies, synergies, and tradeoffs. Moreover, for the actualization of the WEF nexus, existing human resources of the sectors can be trained on its importance, as training offers employees new perspectives on an issue, stimulates their understanding, and gives them technical knowledge - how of WEF security. In addition, the compensation and rewarding system should be efficient in the sectors, emphasizing the management of WEF resources tradeoffs, cutting of wastes, and identification of innovation synergies. This will further ensure the attainment of the goals of Human resource management, as stated by Armstrong [6], which will enable the private sectors to have a good synergy with the public sector.

\subsection{Effect of emerging technologies on management of Water, Energy, and Food (WEF) Nexus}

The extent of operationalization of the theoretical framework of WEF nexus and productivity of human resources depends on the effect and influence of emerging technologies. Several technologies support the management of water, energy, and food (WEF) nexus, such as water-efficient energy systems. These technologies are at various 
Journal of Digital Food, Energy \& Water Systems, 2 (2): 77-120, 2021

ISSN 2709-4529

(C) Centre for Cyber Physical Food, Energy \& Water Systems

research, demonstration, development, and deployment stages. There are wide ranges of technologies optimizing the various nexuses in the water, energy, and food space, like the water-energy nexus, water - food nexus, energy-water nexus, food-water nexus, energy food nexus, and food-energy nexus.

Moreover, Zaidi et al., [143] addressed that water-energy nexus problems and alternatives can be solved using machine-learning contexts of Artificial Intelligence. Furthermore, in optimizing Ethiopia Renewable Energy sources for WEF nexus, Emmanouil, et al., [35] designed a micro grid of solar and small scale hydropower for irrigation water pumping, using the technology of Hybrid optimization of multiple energy resources (HOMER) software and simulations of MODFLOW unsaturated zone flow package. Zhang, Li, Huang \& Ma [144] also designed a copula-based stochastic fractional programming (CSFP) method to solve risks related to arable land, hydropower generation, and water resources, which will help in planning food production, water allocation, and energy generation, used for five (5) countries in Central Asia, Uzbekistan, Tajikistan, Kazakhstan, and Turkmenistan. In addition, Ahmad, Ahmad, Zaindin, and Adhami [3] used a technological novel method called interactive neutrosophic programing approach (INPA) to solve WEF nexus environmental and socio-economic objectives of electricity conversion, optimal energy supply, food production, $\mathrm{CO} 2$ emission control, and water resources allocation.

Furthermore, in applying technology to WEF nexus for different wheat intensive agriculture, Fabiani, et al., [39] used the Variable Rate Technology (VRT), which combines digital and physical technologies such as farm machinery, drones, satellites, artificial intelligence, machine learning, and hyper spectral imaging for the automation of materials like fertilizers, chemical sprays and seeds to land. The Integration of technological innovations into the water - energy and food nexus has steered several technological concepts within the sectors. This includes concepts such as Precision Agriculture and Precision farming [34], vertical farming, hydroponic \& Aquaponics systems [106], Smart grid [133], water reticulation [54], and post-harvest technologies, Irrigation \& Drainage Engineering and Agro-processing [61].

Furthermore, Mekonnen, Burton, Sarwat, and Bhansali [82], in exploring the relationship between the Internet of Things and the WEF nexus, opined that the Internet of Things (IoT) is highly vital in understanding the interdependency of WEF resources, where the authors used wireless sensor networks (WSN) to create real-time data for smart farming. The sensor networks will aid farmers to forecast their agricultural yields, enhance water utilization via smart irrigation control and precisely know when to harvest, which will diminish labor \& 
Journal of Digital Food, Energy \& Water Systems, 2 (2): 77-120, 2021

ISSN 2709-4529

(C) Centre for Cyber Physical Food, Energy \& Water Systems

energy input. This will safeguard environmental sustainability, as farming will be based on precision and efficiency, for more yield, without negative effects on the environment. The authors avowed that IoT would help collect data, whereby the data are analyzed using different algorithms of neural networks, support vector machines (SVM), linear regression, and Artificial neural network (ANN) to make informed decisions in the WEF systems. Using an IoT technology, the authors built a smart farm bed consisting of an off-grid PV panel, smart irrigation, a distributed WSN, and data infrastructure to exploit vegetation yield, diminish the environmental effect, and minimize energy consumption. The advent of IoT technologies helped enhance the effective utilization and integration of data across the WEF resources, making nexus possible effective, and applicable. The management of WEF data is an integral component of ensuring sustainability, especially on operations and delivery of the resources (Etzion \& Aragon - Correa, 2016).

According to Kumar, et al., [62] in the WEF nexus system, IoT is essential, with the following benefits; enabling the user to practice efficient measures, water quality monitoring, enable consumers to become energy \& water efficient, ensures asset performance \& management, ensures food security, water sustainability, energy sustainability, and food sustainability. The authors highlighted the application of IoT in the various WEF components. In the water subsystem of the WEF nexus, IoT applications comprise water quality monitoring, water safety, quality control in water reserves, wastewater management, water transport, monitoring the drought locations, leakage detection in water flow paths, efficient $\&$ systemic water management, and monitoring the water consumption patterns. In the Energy subsystem of WEF nexus, IoT applications include advanced metering infrastructure (AIM), control \& operation of energy-consuming devices (Co - ECD), Battery Energy Management (BEM), Micro Grid (MG), Control of electrical energy system and utility (CEESU), Nano Grid (NG), and Energy system reliability \& stability ( ESRS). Other applications are Fault maintenance in energy systems (FMES), Decrease in Energy Downtime (DED), Energy and Performance Optimization (EPO), Hybrid Energy system intelligent control (HES - IC), energy storage \& Analytics (ESA), Predictive maintenance (PM), and Smart Grid (SG). It also includes Smart Inverters (SI), Hybrid Electric Vehicle Intelligent Control (HEV - IC), Remote monitoring and Reliability (RMR), Supervisory Control and Data Acquisition (SCADA), and Safety \& Security (SS). In the Food Subsystem of WEF nexus, utilization of IoT technologies consist of; storage and handling of food products (SHFP), Food packaging, Food transport, Freshness and quality monitoring of food products that are originated from plant species \& animal meat, and intelligent packaging \& delivery (IPD). Others are Food delivery 
Journal of Digital Food, Energy \& Water Systems, 2 (2): 77-120, 2021

ISSN 2709-4529

(C) Centre for Cyber Physical Food, Energy \& Water Systems

monitoring \& Alert, vegetable washing systems, removing dried and damaged leaves from the food material from the plants, food safety \& security, cereals \& pulses drying at controlled temperature, sorting of vegetables, packed food products \& fruits, online payment of food bills and food safety \& security.

Abe, et al., [1] posited that data science is needed to analyze WEF nexus datasets and the functionality of WEF subsectors technologies, especially in spatial computing, whereby the unavailability of data has become an encumbrance in nexus management. Pitts, et al., (2020) opined that big data. Analytic technology is a technique for modeling the WEF nexus, where there are no reliance or underlying assumptions between variables, and data is the foundational input in the model. This makes it less prone to error and uncertainty, quick to develop, and shows tradeoffs in the nexus, thereby highlighting areas that will adversely affect sustainability issues in the nexus.

Therefore, the significant effect of emerging technologies is the emergence of innovations in the water, energy, and food space, thereby shaping the nature of the nexus. Moreover, the Artificial Intelligence (AI), Big data analytics, and Internet of Things (IoT), are the significant technologies steering the water, energy, and food space.

\subsection{Conclusion and Recommendation}

The paper explained the various theories aiding the WEF nexus, such as Institutional theory, Malthusian theory of population theory, Game theory, Securitization theory, Innovation Diffusion theory, and Technology Acceptance Model. The theory revealed the intrinsic nature of the WEF resources and their interrelationship with human activities. The theoretical framework shows that human activities will continue to shape the three resources' nexus and determine the extent of security of the three resources. Moreover, the theories highlight the significance of human resources for actualizing the WEF nexus. The paper also highlights the importance of recruiting human resources in the WEF sector with a nexus thinking to mitigate against silo mentality in the WEF sectors. Furthermore, the research revealed how Artificial Intelligence (AI), Internet of Things (IoT), and Big data as emerging technologies shape the WEF nexus interactions with innovations. Conclusively, there is an interaction between the theories of WEF nexus and Human resources management of the nexus, which will affect the extent of the innovations introduced by emerging technologies.

Therefore, it is recommended that there be a quantification of the theories introduced in this research to know the extent of application and magnitude of effect. Moreover, there is a need for periodic and consistent training of current human resources in the water, energy, and food sectors on WEF nexus thinking. In addition, there is a need for capital and human 
Journal of Digital Food, Energy \& Water Systems, 2 (2): 77-120, 2021

ISSN 2709-4529

(C) Centre for Cyber Physical Food, Energy \& Water Systems

resource investment on emerging technologies shaping the WEF nexus for mass commercialization and customization of innovations introduced in the water, energy, and food space.

\subsection{References}

[1] Abe, N., Xie, Y., Shekhar, S., Apte, C., Kumar, V., Tuinistra, M., and Vatsavai, R.R., (2016). Data science of Food, Energy and Water: A workshop Report. At the 22nd ACM SIGKDD conference on Knowledge and Data Discovery (KDD), a workshop on Data Science for Food, Energy and Water (DSFEW).

[2] Adepoju, O.O., and David, L.O., (2020). Covid - 19: Institutionalizing the production of Personal Protective Equipments (PPE) for safety of Health workers through Bilateral Relations between Nigeria and Japan. Proceedings of the $3^{\text {rd }}$ Annual African Association for Japanese studies (AAJS) on Environment Technology and Covid -19 (Online), on $6^{\text {th }}$ $-7^{\text {th }}$ October, 2020.

[3] Ahmad, F., Ahmad, S., Zaindin, M., and Adhami, A.Y., (2021). Robust Neutrosophic Modeling and Optimization Approach for Integrated Energy-Food-Water Security Nexus Management under Uncertainty. Water, 13(121), Pp. 1 - 26. https://doi.org/10.3390/w13020121

[4] Anfara, V.A. \& Mertz N.T. (2015) Theoretical frameworks in qualitative research (2nd ed). Los Angeles: Sage

[5] Armstrong, M., (2016), Armstrong's Handbook of Strategic Human Resource Management, London: Kogan Page

[6] Armstrong, M., and Taylor, S., (2015), Armstrong's Handbook of Human Resource Management Practice, London: Kogan Page

[7] Balzacq, T., (2005). The Three Faces of Securitization: Political Agency, Audience and Context. European Journal of International Relations 11:2, 171-201.

[8] Balzacq, T., (2011). A Theory of Securitization: Origins, Core Assumptions, and Variants. In Securitization Theory: How Security Problems Emerge and Dissolve, edited by Thierry Balzacq. London: Routledge.

[9] Berthod, O., (2016). Institutional Theory of Organizations. A. Farazmand (ed.), Global Encyclopedia of Public Administration, Public Policy, and Governance, DOI 10.1007/9783-319-31816-5_63-1

[10] Bizikova, L., Roy, D., Swanson, D., Venema, H. D. and McCandless, M. (2013). The Water-Energy-Food Security Nexus: Towards a Practical Planning and Decision-Support Framework for Landscape Investment and Risk Management. International Institute for Sustainable Development. http://www.iisd.org/library/water-energy-food-security-nexustowards-practical-planning-and-decision-support-framework 
Journal of Digital Food, Energy \& Water Systems, 2 (2): 77-120, 2021

ISSN 2709-4529

(C) Centre for Cyber Physical Food, Energy \& Water Systems

[11] Bockova, K. H., Slavikova, G., and Gabrhel, J., (2015). Game Theory as a tool of Project Management. $20^{\text {th }}$ International Scientific Conference Economics and Management (ICEM - 2015), Social and Behavioral Sciences, 213 (2015), Pp. 709 - 715. Doi: 10.1016/j.sbspro.2015.11.491.

[12] Botai J. O., Botai C. M., Ncongwane K. P., Mpandel S., Nhamo L., Masinde M., Adeola A. M., Migistu M. G., Tazvinga H. T., Murambadoro M. D., et al. (2021). A Review of the Water-Energy-Food Nexus Research in Africa. Sustainability 2021, 13,1762. https://doi.org/10.3390/su13041762

[13] Boxall P and Purcell J (2016), Strategy and Human Resource Management, London: Palgrave Macmillan

[14] Bradbury - Jones, C., Taylor, J., and Herber, O., (2014). How theory is used and articulated in qualitative research: Development of a new typology. Social Science \& Medicine, 120 (2014), Pp. 135 - 141. http://dx.doi.org/10.1016/j.socscimed.2014.09.014.

[15] Buzan B., (2008). The Changing Agenda of Military Security, in Hans Günter Brauch et al. Eds., Globalization and Environmental Challenges, Berlin, Springer, pp. 553-560.

[16] Buzan, B., \& Wæver, O., (2003). Regions and Powers. Cambridge: Cambridge University Press.

[17] Buzan, B., Wæver, O., and De Wilde, J., (1998) Security: A New Framework for Analysis. Boulder: Lynne Rienner.

[18] Chand, S., (2017). Malthusian Theory of Population: Criticisms and Applicability. Your Article Library. Retrieved November 29, 2017, from http:/www.yourarticlelibrary.com/ population/malthusian-theory-of-population- criticisms-and-applicability/10885

[19] Charrett, C., (2009). A critical application of securitization theory: Overcoming the Normative Dilemma of writing security. International Catalan Institute for Peace. ISSN: 20135793.

[20] Chen, T., and Ni, Y., (2019). IOP Conf. Ser.: Earth Environ. Sci. 218012031

[21] Choe, M., and Noh, G., (2018). Combined Model of Technology Acceptance and Innovation Diffusion Theory for Adoption of Smartwatch. International Journal of contents, 14(3), Pp. 32 - 38. https://doi.org/10.5392/IJoC.2018.14.3.032

[22] Chowdhury, M. N. M., \& Hossain, M. (2018). Population growth and economic development in Bangladesh: Revisited Malthus. Munich Personal RePEc Archieve, 91216. Retrieved on June 25, 2020 from https://mpra.ub.unimuenchen.de/91216/1/MPRA paper 90826.pdf.

[23] Chu, Z., Xu, J., Lai, F., and Collins, B. J., (2018). Institutional Theory and Environmental Pressures: The Moderating Effect of Market Uncertainty on Innovation and Firm Performance. IEEE Transactions on Engineering Management, 65(3), Pp. 392 - 403.

[24] Coles, N., and Hall, P., (2012). Water, Energy and Food security. Technology challenges of thinking in a nexus perspective. IEEE Technology and Society in Asia Conference, Singapore, October $26-28,2012$. 
Journal of Digital Food, Energy \& Water Systems, 2 (2): 77-120, 2021

ISSN 2709-4529

(C) Centre for Cyber Physical Food, Energy \& Water Systems

[25] Collins, C.S., and Stockton, C.M., (2018). The Central Role of Theory in Qualitative Research. International Journal of Qualitative Methods, 7(2018), Pp. 1 - 10. Doi: $10.1177 / 1609406918797475$

[26] Comyns, B., (2018). Climate Change reporting and multinational Companies: Insights from Institutional theory and International business. Accounting Forum, 42(2018), Pp. 65 - 77.

[27] Creswell, J.W., (2007). Qualitative Inquiry and Research Design: Choosing Among Five Approaches, second ed. Sage Publication, Thousand Oaks.

[28] Daher, B., Saad, W., Pierce, S.A., Hulsmann, S., and Mohtar, R. H., (2017). Tradeoffs and Decision Support tools for FEW Nexus - Oriented Management. Curr Sustainable Renewable Energy Rep, 4(2017), Pp. 153 - 159. Doi: 10.1007/s40518-017-0075-3.

[29] Daniel, Mann, Johns and Mendenhall. (1998). Technical Assessment of Residential and Small Commercial Emerging Technologies. San Francisco, CA: Pacific Gas \& Electric Company.

[30] Davis, F. (1989). Perceived usefulness, perceived ease of use, and user acceptance of information technology. MIS Quarterly, 13(3), 319-340. doi:10.2307/249008

[31] Dearing, J.W., and Cox, J.G., (2018). Diffusion of Innovations Theory, Principles, and Practice. Health Affairs, 37 (2), Pp. 183 - 190. Doi: 10.1377/hlthaff.2017.1104.

[32] Deslonde, V., and Becerra, M., (2018). The Technology Acceptance Model (TAM): Exploring School Counselors' Acceptance and use of Naviance. The Professional Counselor, 8(4), Pp. 369 - 382. doi:10.15241/vd.8.4.369

[33] DiMaggio, P.J., and Powell, W. W., (1983). The Iron Cage Revisited: Institutional Isomorphism and collective rationality in organizational fields: American Sociological Review, Pp. $147-160$.

[34] Dwivedi, A., Naresh, R.K., Kumar, R., Yadav, R.S., and Kumar, R., (2017). Precision Agriculture. Chapter Five, In: Promoting Agri - horticultural, technological innovations. Parmar Publishers \& Distributors, Dhanbad, Jharkhand, Pp. 83-105.

[35] Emmanouil, S., Philhower, J., Macdonald, S., Khadim, F.K., Yang, M., Atsbeha, E., Nagireddy, H., Roach, N., Holzer, E., and Anagnostou, E.N., (2021). A comprehensive Approach to the design of a renewable Energy Microgrid for rural Ethiopia: The Technical and Social Perspectives. Sustainability, 13(3974). https://doi.org/10.3390/su13073974

[36] Endo, A.; Burnett, K.; Orencio, P.M.; Kumazawa, T.; Wada, C.A.; Ishii, A.; Tsurita, I.; Taniguchi, M. (2015) Methods of the water-energy food nexus (2015). Water 2015, 7, 5806-5830.

[37] Eren, M. V. (2020). Nüfus artışı ile kalkınma arasındaki ilişki: Sahra-altı Afrika ülkeleri üzerine ampirik bir analiz. Uluslararası İktisadi ve İdari İncelemeler Dergisi, 27, 141-158

[38] Evans, B. and Reid, J. (2014). Resilient life: The art of living dangerously. Cambridge/Malden: Polity Press.

[39] Fabiani, S., Vanino, S., Napoli, R., Zajicek, A., Duffkova, R., Evangelou, E., and Nino, P., (2020). Assessment of the Economic and Environmental sustainability of Variable Rate 
Journal of Digital Food, Energy \& Water Systems, 2 (2): 77-120, 2021

ISSN 2709-4529

(C) Centre for Cyber Physical Food, Energy \& Water Systems

Technology (VRT) application in different wheat intensive European Areas. A water energy foo nexus approach. Environmental Science and Policy 114(2020), Pp. 366 - 376. https://doi.org/10.1016/j.envsci.2020.08.019.

[40] FAO. (2014). The Water-Energy-Food Nexus A new approach in support of food security and sustainable agriculture. Food and Agriculture Organization of the United Nations, Rome.

[41] Floyd, R., (2011). Can Securitization Theory Be Used in Normative Analysis? Towards a Just Securitization Theory. Security Dialogue 42 (4-5): 427-439.

[42] Foran, T. (2015). Node and regime: Interdisciplinary analysis of water-energy-food nexus in the Mekong region. Water Alternatives 8(1): 655-674

[43] Friel, D., (2017). Understanding Institutions: Different Paradigms, different conclusions. $\begin{array}{llllll}\text { Revista de Administração } & 52 & \text { (2017). } & \text { Pp. } & 212-214\end{array}$ http://dx.doi.org/10.1016/j.rausp.2016.12.001

[44] Garcia, F. A. P., (2014). Game Theory application for the assessment of complex energy resources nexus in policy development. Master Degree Thesis, Imperial College London.

[45] Ghodsvali, M.; Krishnamurthy, S.; and de Vries, B (2019). Review of transdisciplinary approaches to food-water-energy nexus: A guide towards sustainable development. Environ. Sci. Policy 2019, 101, 266-278.

[46] Glover, J., Champion, D., Daniels, K., and Dainty, A., (2013). An Institutional theory Perspective on Sustainable Practices across the Dairy Supply chain. Institutional Theory and Sustainable Energy Practices.

[47] Grant, C., and Osanloo, A., (2014). Understanding, Selecting, and Integrating a Theoretical Framework in Dissertation Research: Creating the Blueprint for your House. Administrative Issues Journal: Connecting Education, Practice, and Research, 4(2), Pp. 1 - 15, Doi: 10.5929/2014.4.2.9.

[48] Gupta, K. S., (2012). Population Growth, Malthusian Concern and Sustainable Development - Some Key Policies and Demographic Issues in India. Global Journal of Human Social Science. 12(3), Pp. 20 - 32.

[49] Gyawali, D. (2015). Nexus Governance: Harnessing Contending Forces at Work. Nexus Dialogue Synthesis Papers. Switzerland.

[50] Halaweh, M., (2013). Emerging Technology: What is it? Journal of Technology Management \& Innovation, 8(3), Pp. 108 - 115.

[51] Hall, P.,\& Taylor,R.(1996). Politicalscience and the three newinstitutionalisms. Political Studies, 44, 936-957

[52] Hameed, T., (2021). Productivity and Human Resources. The People Development Magazine. Retrieved from: https://peopledevelopmentmagazine.com/2021/10/31/productivity-and-human-resources/ Accessed 22/11/2021. 
Journal of Digital Food, Energy \& Water Systems, 2 (2): 77-120, 2021

ISSN 2709-4529

(C) Centre for Cyber Physical Food, Energy \& Water Systems

[53] Hoff, H., (2011). Understanding the Nexus. Background Paper for the Bonn 2011 Conference: the Water, Energy and Food Security Nexus. Stockholm Environment Institute, Stockholm.

[54] Hydroserv (2021). Water Reticulation. Hydroserv. Retrieved from https://www.hydroserv.com.au/water-reticulation/ (Accessed $8^{\text {th }}$ October, 2021).

[55] IEA, International Energy Agency, (2014). Energy Security. IEA Energy Technology Systems Analysis Programme. Paris. 〈http://www.iea.org/topics/energysecurity/.

[56] Ja Kim, M., Lee, C., and Contractor, N. S., (2019). Seniors' usage of mobile social network sites: Applying theories of innovation diffusion and uses and gratifications. Computers in Human Behavior, 90 (2019), Pp. 60 - 73. https://doi.org/10.1016/j.chb.2018.08.046

[57] Jaradat, M., \& Al-Mashaqba, A. M. (2014). Understanding the adoption and usage of mobile payment services by using TAM3. International Journal of Business Information Systems, 16(3), 271-296.

[58] Jennings, P.D., and Zandbergen, P.A., (1995). Ecologically sustainable organizations: an institutional approach. The Academy of Management Review 20 (4), 1015-1052.

[59] Jepperson, R. L., \& Meyer, J. W. (1991). The Public Order and the Construction of Formal Organization, in the New Institutionalism in Organizational Analysis, edited by W. Powell and PJ Di Maggio.

[60] Jwaifell, M., and Gasaymeh, A., (2013). Using the Diffusion of Innovation Theory to Explain the Degree of English Teachers' Adoption of interactive whiteboards in the modern systems school in Jordan: A case study. Contemporary Educational technology, 4(2), Pp. $138-149$.

[61] Kambolam (2021). Post-Harvest Technology. Kerala Agriculture University, Thrissur. Retrieved from https://www.amickau.nic.in/index.php?option=com_content\&task=view\&id=53\&Itemid= 87. (Accessed $8^{\text {th }}$ October, 2021).

[62] Kumar, N.M., Dash, A., and Singh, N.K., (2018). Internet of Things (IoT): An Opportunity for Energy - Food - Water Nexus. 2018 International Conference on Power Energy, Environment and Intelligent Control (PEEIC) G. L. Bajaj Inst. of Technology and Management Greater Noida, U. P., India, Apr 13-14, 2018

[63] Leck, H.; Conway, D.; Bradshaw, M.; and Rees, J. (2015). Tracing the water-energy-food nexus: Description, theory and practice: Tracing the water-energy-food nexus. Geogr. Compass 2015, 9, 445-460.

[64] Lederman, N.G., and Lederman, J.S., (2015). What is a Theoretical Framework? A Practical Answer. Journal of Teacher Education, 26 (2015), Pp. 593 - 597. Doi: 10.1007/s10972 $015-9443-2$.

[65] Leeming, D. (2018). The use of theory in qualitative research. Journal of Human Lactation, 34 (4), 668-673 
Journal of Digital Food, Energy \& Water Systems, 2 (2): 77-120, 2021

ISSN 2709-4529

(C) Centre for Cyber Physical Food, Energy \& Water Systems

[66] Leese, M. and Meisch, S. (2015). Securitizing sustainability? Questioning the 'water, energy and food-security nexus'. Water Alternatives 8(1): 695-709

[67] Lewis, A.C., Cardy, R. L., and Huang, L. S. R., (2019). Institutional Theory and HRM: A New Look. Human Resource Management Review, 29 (2019), Pp. 316 - 335. https://doi.org/10.1016/j.hrmr.2018.07.006

[68] Li, F., and Zhou, W., (2015). The Impact of the Game between stakeholders on the production of Farmland. Agricultural Sciences, 6(2015), Pp. 1317 - 1323. http://dx.doi.org/10.4236/as.2015.611126

[69] Lou, Antonio T. F. and Li, Eldon Y., (2017). Integrating Innovation Diffusion Theory and the Technology Acceptance Model: The adoption of blockchain technology from business managers' perspective. ICEB 2017 Proceedings. 44. http://aisel.aisnet.org/iceb2017/44

[70] Lüger, T., (2018) : The principle of population vs. the Malthusian trap: A classical retrospective and resuscitation, Darmstadt Discussion Papers in Economics, No. 232, Technische Universität Darmstadt, Department of Law and Economics, Darmstadt, http://nbn-resolving.de/urn:nbn:de:tuda-tuprints-73419

[71] Lupovici, A., (2014). The Limits of Securitization Theory: Observational Criticism and the curious absence of Israel. International Studies Review, 16 (2014), Pp. 390 - 410.

[72] Mabhaudhi, T.; Mpandeli, S.; Nhamo, L.; Chimonyo, V.G.; Nhemachena, C.; Senzanje, A.; Naidoo, D.; and Modi, A.T. (2018). Prospects for improving irrigated agriculture in southern Africa: Linking water, energy and food. Water 2018, 10, 1881.

[73] Madani, K., (2010). Game Theory and Water Resources. Journal of Hydrology, 381(2010), Pp. 225 - 238. Doi: 10.1016/j.jhydrol.2009.11.045.

[74] Madani, K., Darch, G., Parra, F., and Workman, M., (2015). Using Game theory to address Modern Resource Management Problems. Grantham Institute Briefing note No 2, September 2015, Imperial College London.

[75] Madhlopa, A., Keen, S., Sparks, D., and Moorlach, M., (2014). Draft policy framework for efficient water use in energy production. Rondebosch, South Africa: Energy Research Centre. $\quad$ http://www.erc.uct.ac.za/sites/default/files/image tool/images/119/Papers2014/14-Madhlopa-etal-Efficient water use energy production.pdf

[76] Madsen, J. B., Robertson, P. E., and Ye, L. (2019). Malthus was right: Explaining a millennium of stagnation. European Economic Review, 118, 51-68

[77] Malthus, T. (1978). An Essay on the Principle of Population. Printed for J. Johnson, in St. Paul's Church-Yard, London, UK.

[78] March, J.G., and Olsen, J.P. (1989). Rediscovering institutions: The organizational basis of politics. NewYork: Free Press

[79] McGrane, S.J., Acuto, M., Artioli, F., Chen, P., Comber, R., Cottee, J., Farr - Wharton, G., Green, N., Helfgott., A., Larcom, S., McCann, J.A., O’Reilly, P., Salmoral, G., Scott, M., Todman, L.C., Gevelt, T.V., and Yan, X., (2018). Scaling the nexus: Towards integrated 
Journal of Digital Food, Energy \& Water Systems, 2 (2): 77-120, 2021

ISSN 2709-4529

(C) Centre for Cyber Physical Food, Energy \& Water Systems

Frameworks for analyzing Water, Energy, and Food. The Geographical Journal, 185 (2019), Pp. 419 - 431. Doi: 10.1111/geoj.12256.

[80] Mclnnes, C., and Rushton, S., (2011). HIV/AIDS and Securitization theory. European Journal of International Relations, 19(1), Pp. 115 - 138. DOI: 10.1177/1354066111425258

[81] Meadows, D. H., Meadows, D. L., Randers, J. \& Behrens, W. W. (1972) The Limits to Growth. Universe, New York.

[82] Mekonnen, Y., Burton, L., Sarwat, A., and Bhansali, and Bhansali (2018). IoT Sensor Network Approach for Smart Farming: An Application in Food, Energy and Water System. IEEE, $978-1-5386-5566-5$.

[83] Meleis, A. I., (2007). Theoretical Nursing. Development and Progress, Fourth ed. Lippincott Williams \& Wilkins.

[84] Meyer, J. W., and Rowan, B., (1977). Institutionalized Organizations: Formal Structure as myth and ceremony. American Journal of Sociology, 83(2), Pp. $340-363$.

[85] Meyer, S., and Ward, P., (2014). How to use social theory within and throughout qualitative research in healthcare contexts. Sociol. Compass, 8(5), Pp. $525-539$.

[86] Mojelan, M. M., Satari, S., Soleimani, T., and Daryani, S. M., (2020). Human Resource Productivity Indicators Factor Analysis: Emphasizing Scientific and Ethical Factors. International Journal of Ethics \& Society (IJES), 2(3), Pp. 1 - 11.

[87] Moore, G.C. and Benbasat, I. (1991) 'Development of an Instrument to Measure the Perceptions of Adopting and Information Technology Innovation'. Information Systems Research, 2(3), 192-222.

[88] Mueller, B., and Urbach, N., (2013). The Why, What, and How of Theories in is Research. Research Methods and Philosophy. Thirty fourth International Conference on Information Systems, Milan, 2013. Pp. 1- 25.

[89] Mytelka, L., (2000). Local systems of innovation in a globalized world economy. Industry and Innovation 7(1), 33-54. https://doi.org/10.1080/713670244

[90] National Intelligence Council. (2012). Global trends 2030: Alternative worlds. http://globaltrends2030.files.wordpress.com/2012/11/global-trends-2030november2012.pdf

[91] North, D.C., (1990). Institutions, Institutional change, and Economic Performance. Cambridge University Press, Cambridge, UK.

[92] O'riordan, J., (2017). The practice of Human Resource Management. Institute of Public Administration.

[93] Okunola, A. M., Nathaniel, S. P., and Festus, V. B., (2018). Revisiting Population Growth and Food Production Nexus in Nigeria: An ARDL Approach to Co - integration. Agricultural and Resource Economics: International Scientific E - Journal, 4(4), Pp 41 51.

[94] Osibanjo, A. O., and Adeniji, A. A., (2012). Human Resource Management: Theory \& Practice. Pumark Nigeria Limited. ISBN: $978-978-50666-8$-5. 
Journal of Digital Food, Energy \& Water Systems, 2 (2): 77-120, 2021

ISSN 2709-4529

(C) Centre for Cyber Physical Food, Energy \& Water Systems

[95] Öztürk, L. (2012). Türkiye'de illerin yoksulluk nedeni olarak toplam doğurganlık hızları: Yatay kesit bir analiz, 1990-2000. Uludağ Üniversitesi İktisadi ve İdari Bilimler Fakültesi Dergisi, 21(1), 93-210

[96] Paul, D. (1994). Why are institutions the carriers of history? Path dependence and the evolution of conventions, organizations and institutions. Structural Change and Economic Dynamics, 5/2, 1-24.

[97] Pigott, T. D., (2017). The Role of Theory in Quantitative Data Analysis. The BERA/SAGE Handbook of Educational Research: 19, 2017. Retrieved from Loyola eCommons, Education: School of Education Faculty Publications and Other Works.

[98] Rahman, M. (2018). Validity of Malthusian theory of population in 20th century in terms of using scientific technology to the economic growth and strength. International Journal of Tax Economics and Management, 1(1), 13-21.

[99] Raoof, O., and Al - Raweshidy, H., (2010). Theory of Games: An Introduction. Research Gate. Pp. 1 - 13. Doi: 10.5772/46930.

[100] Rasul, G. \& Sharma, B. (2015). The nexus approach to water-energy-food security: an option for adaptation to climate change. Climate Policy, 16, 682-702.

[101] Robertson, T.S., (1967). The process of Innovation and the diffusion of Innovation. Journal of Marketing, 31(1), Pp. $14-19$.

[102] Rockström, J.; Steffen, W.; Noone, K.; Persson, Å.; Chapin III, F.S.; Lambin, E.; Lenton, T.M.; Scheffer, M.; Folke, C. and Schellnhuber, H.J. (2009). Planetary boundaries: Exploring the safe operating space for humanity. Ecology and Society 14(2).

[103] Rockström, J.; Steffen, W.; Noone, K.; Persson, Å.; Chapin III, F.S.; Lambin, E.F.; Lenton, T.M.; Scheffer, M.; Folke, C.; Schellnhuber, H.J.; Nykvist, B.; de Wit, C.A.; Hughes, T.; van der Leeuw, S.; Rodhe, H.; Sörlin, S.; Snyder, P.K.; Costanza, R.; Svedin, U.; Falkenmark, M.; Karlberg, L.; Corell, R.W.; Fabry, V.J.; Hansen, J.; Walker, B.; Liverman, D.; Richardson, K.; Crutzen, P. and Foley, J.A. (2009). A safe operating space for humanity. Nature 461(7263): 472-475.

[104] Rogers, E. M. (1983). Diffusion of innovations. Third edition. New York. Free Press

[105] Rogers, E.M. (2003). Diffusion of innovations (5th ed.). New York: Free Press.

[106] Royston, R.M., and Pavithra, M.P., (2018). Vertical Farming: A Concept. International Journal of Engineering and Techniques, 4(3), Pp. 500 - 506.

[107] Sahin, I., (2006). Detailed Review of Rogers' Diffusion of Innovations Theory and Educational Technology - Related studies based on Rogers Theory. The Turkish online Journal of Educational Technology - TOJET, 2(3), Pp. 1 - 10.

[108] Sakanko, M.A. \& David, J. (2018). An Econometrics Validation of Malthusian Theory: Evidence in Nigeria. Signifikan: Jurnal Ilmu Ekonomi. Vol. 7 (1): 77 - 90. doi: http//dx.doi.org/10.15408/sjie.v7i1.6461

[109] Scharpf, F. W. (1997). Games Real Actors Play: Actor-Centered Institutionalism in Policy Research. Westview Press, Boulder, CO 
Journal of Digital Food, Energy \& Water Systems, 2 (2): 77-120, 2021

ISSN 2709-4529

(C) Centre for Cyber Physical Food, Energy \& Water Systems

[110] Schmidt, V. (2010). Give peace a chance: Reconciling four (not three)"New Institutionalisms”. In D. Beland, \& R. Cox (Eds.), Ideas and politics in social science research. Oxford: Oxford University Press.

[111] Schoenfeld, A. H. (2010). Reflections of an accidental theorist. Journal for Research in Mathematics Education, 41(2), 104-116

[112] Scott, W., (1991) Unpacking institutional arguments. In: Powell W, Di Maggio P (eds) The New Institutionalism in Organizational Analysis. University of Chicago Press, Chicago, pp 164-182

[113] Scott, W., (2013). Institutions and Organizations: Ideas, Interests, Identities. Sage, Thousand Oaks.

[114] Scott, A., (2017). Making governance work for water - energy - food nexus approaches. Working Paper. Climate and Development Knowledge Network (CDKN).

[115] Scott, W. R., (1987). The Adolescence of Institutional Theory. Administrative Science Quarterly, Pp. $493-511$.

[116] Seth, T. (2017). Malthusian Theory of Population: Explained with its Criticism. Retrieved November 29, 2017, from http://www.economicsdiscussion.net/articles/ malthusiantheoryof-population-explained-with-its-criticism/1521

[117] Silva, C.C., and Pereira, A. E., (2019). International Security and New Threats: Securitization and Desecuritazation of drug trafficking at the Brazilian Borders. Contexto Internacional, 4(1), Pp. 209 - 234. http://dx.doi.org/10.1590/S0102-8529.2019410100011

[118] Silva, P.M., and Dias, G.A., (2007). Theories about Technology Acceptance: Why the users accept or reject the Information Technology. Brazillian Journal of Information Science, 1(2), Pp. $69-86$.

[119] Slimane, K. B., Chaney, D., Ashlee, H., and Leca, B., (2019). Bringing Institutional theory to marketing: Taking stock and future research directions. Journal of Business research, 105(2019), http://dx.doi.org/10.1016/j.jbusres.2019.06.042

[120] Snyder, H., (2019). Literature Review as a research Methodology: An overview and guidelines. Journal of Business Research, 104(2019), Pp. 333 - 339. https://doi.org/10.1016/j.jbusres.2019.07.039

[121] Staupe - Delgado, R., (2019). The Water - Energy - Food - Environmental security nexus: Moving the debate forward. Environment, Development and Sustainability, https://doi.org/10.1007/s10668-019-00467-5

[122] Stein, C., Barron, J., and Moss, T., (2014). Governance of the nexus: from Buzz words to a strategic action perspective. Nexus Network Think Piece Series, Paper 003 (November 2014). https://www.researchgate.net/publication/269694408

[123] Steinmo, S., Thelen, K., and F. Longstreth (1992) Structuring Politics: Historical Institutionalism in Comparative Analysis (Cambridge: Cambridge University Press).

[124] Storey J., (2007). Human Resource Management: A Critical Text, London: Thompson Learning 
Journal of Digital Food, Energy \& Water Systems, 2 (2): 77-120, 2021

ISSN 2709-4529

(C) Centre for Cyber Physical Food, Energy \& Water Systems

[125] Sudibyo, Y. A., and Jianfu, S., (2015). Institutional theory for explaining corruption: An empirical study on public sector organizations in China and Indonesia. Corporate Ownership \& Control.13(1), Pp. 817 - 823.

[126] Terrapon - Pfaff, J., Ortiz, W., Dienst, C., and Grone, M., (2018). Energising the WEF nexus to enhance sustainable development at local level. Journal of Environmental Management, 223(2018), Pp. 409 - 416. https://doi.org/10.1016/j.jenvman.2018.06.037

[127] Tesfatsion, L., (2019). Game Theory: Basic Concepts and Terminology. http://www2.econ.iastate.edu/tesfatsi/GameDef.pdf

[128] UN (United Nations), (2015). Transforming our World: The 2030 Agenda for Sustainable Development. A/RES/70/1. Available at: https://sustainabledevelopment.un.org/content/documents/21252030\%20Agenda $\% 20$ for $\%$ 20Sustainable\%20Development\%20web.pdf Accessed November 2021

[129] UN Water. (2013). Water Security and the Global Water Agenda. UN-Water Analytical Brief. United Nations University, Hamilton, Canada.

[130] Unat, E. (2020). A review of Malthusian theory of population under the scope of human capital. Focus on Research in Contemporary Economics (FORCE), 1(2), 132-147

[131] UNESCO (2019). Leveraging intersectorality for sustainable water security and peace. UNESCO International Water Conference, $9^{\text {th }}$ January, 2019. https://en.unesco.org/sites/default/files/item_4.4 ihp_tech_bur_19 unesco_waterconferen ce conceptnote extrashort 9jan2019 en.pdf

[132] Venkatesh, V., and Davis, F. D., (2000). A theoretical extension of the technology acceptance model: Four Longitudinal field studies. Management science, 46(2), Pp. 186 204.

[133] Vijayapriya, T., and Kothari, D.P., (2011). Smart Grid: An Overview. Smart Grid and Renewable Energy, 2011(2), Pp. 305 - 311. Doi:10.4236/sgre.2011.24035

[134] Von Neumann, J., and Morgenstern, O., (1944, 1947, 1953). Theory of games and economic behavior, 1919 Princeton University Press, Princeton.

[135] Wæver, Ole. (1995) Securitization and Desecuritization. In On Security, edited by Ronnie D. Lipschutz. New York: Columbia University Press.

[136] Weaver, O., (1989). 'Security, the speech act: analyzing the politics of a word.' In Research Training Seminar. Jerusalem/Tel Aviv, 25-26 June 1989. Copenhagen: Centre of Peace and Conflict Research.

[137] Wei, S.M.A., (2008). On the use of Game theoretic models for water resources management. Brandenburg University of Technology in Cottbus. Faculty of Environmental Sciences and Process Engineering. A PhD Thesis.

[138] Wilkinson, C., (2007). The Copenhagen School on Tour in Kyrgyzstan: Is Securitization Theory Useable Outside Europe? Security Dialogue 38 (1): 5-25.

[139] Williamson, O., (2000). The new institutional economics: Taking stock, looking ahead. Journal of Economic Literature, 38/3, 595-613 
Journal of Digital Food, Energy \& Water Systems, 2 (2): 77-120, 2021

ISSN 2709-4529

(C) Centre for Cyber Physical Food, Energy \& Water Systems

[140] Wingo., N. P., Ivankova, N. V., \& Moss, J. A. (2017) Faculty perceptions about teaching online: exploring the literature using the technology acceptance model as an organizing framework, Online Learning 21(1), 15-35. doi: 10.10.24059/olj.v21i1.761

[141] World Economic Forum Water Initiative. (2011). Water security: The water-food-energyclimate nexus. Washington/Covelo/London: Island Press.

[142] World Economic Forum, WEF (2011). Water Security: The Water-Energy-Food-Climate Nexus. World Economic Forum Initiative.

[143] Zaidi, S.M.A.; Chandola, V.; Allen, M.R.; Sanyal, J.; Stewart, R.N.; Bhaduri, B.L.; McManamay, R.A. Machine learning for energy-water nexus: Challenges and opportunities. (2018). Big Earth Data 2018, 2, 228-267.

[144] Zhang, Y.F., Li, Y.P., Huang, G.H., and Ma, Y., (2021). A Copula - based Stochastic fractional programming method for optimizing water - food - energy nexus system under uncertainty in the Aral Sea Basin. Journal of Cleaner Production, 292(2021), Pp. 1 - 13. https://doi.org/10.1016/i.jclepro.2021.126037

[145] Zhao, S., Liu, M., Zhu, C.J., and Liu, H., (2020). The role of Leadership in human resource management: Perspectives and Evidence from Asia Pacific: Guest Editors. Asian Pacific Business Review, Pp. 1 - 5. https://doi.org/10.1080/13602381.2020.1779496

[146] Zhu, W., I. K. Chew, and W. D. Spangler. (2005). CEO Transformational Leadership and Organizational Outcomes: The Mediating Role of Human-capital-enhancing Human Resource Management. The Leadership Quarterly 16 (1): 39-52. 